\title{
DIAGNOSE NUTRICIONAL DE POTÁSSIO EM DUAS ESPÉCIES DE BRAQUIÁRIA
}

\author{
Waldssimiler Teixeira de Mattos \\ Engenheiro Agrônomo
}

Orientador: Prof. Dr. FRANCISCO ANTONIO MONTEIRO

Dissertação apresentada à Escola Superior de Agricultura "Luiz de Queiroz", Universidade de São Paulo, para obtenção do título de Mestre em Agronomia, Área de Concentração: Solos e Nutrição de Plantas.

\author{
P I R A C I C A B A \\ Estado de São Paulo - Brasil \\ Setembro - 1997
}


Dados Internacionais de catalogação na Publicação (CIP) DIVISĀO DE BIBLIOTECA E DOCUMENTAÇĀO - Campús "Luiz de Queiroz"/USP

Mattos, Waldssimiler Teixeira

Diagnose nutricional de potássio em duas espécies de braquiária / Waldssimiler

Teixeira de Mattos. - Piracicaba, 1997

74 p. : il.

Dissertaçăo (mestrado) - Escola Superior de Agricultura Luiz de Queiroz, 1997.

Bibliografia.

1. Capim braquiária 2. Diagnose foliar 3. Matéria seca 4. Nutriçăo vegetal 5. Potássio I. Título

CDD 633.2 


\section{DIAGNOSE NUTRICIONAL DE POTÁSSIO EM DUAS ESPÉCIES DE BRAQUIÁRIA}

WALDSSIMILER TEIXEIRA DE MATTOS

Aprovado em: 21.10.1997

Comissão julgadora:

Prof. Dr. FRANCISCO ANTONIO MONTEIRO

ESALQ/USP

Prof. Dr. ANTONIO ROQUE DECHEN

ESALQ/USP

Dr. JOAQUIM CARLOS WERNER

IZ/SAA

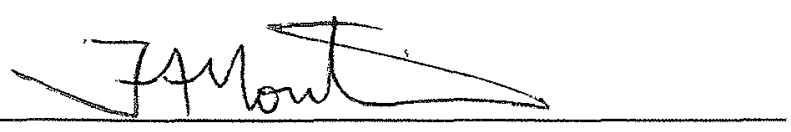

Prof. Dr. FRANCISCO ANTONIO MONTEIRO

Orientador 
Aos meus pais, Herbert e Maria Cecília, ao meu irmão Wlasterniler e aos meus avós,

\title{
OFEREÇO.
}

\begin{abstract}
A minha noiva ADRIANA pelo amor, apoio e incentivo,
\end{abstract}

\section{DEDICO.}




\section{AGRADECIMENTOS}

Ao Prof. Dr. Francisco Antonio Monteiro pela excelente orientação, pelo apoio e principalmente pela amizade.

Ao Prof. Dr. Quirino Augusto de Camargo Carnello, pela amizade, atenção, ajuda e sugestões.

Ao Prof. Dr. Antonio Roque Dechen pela amizade e constante incentivo.

Ao Prof. Dr. Henrique Paulo Haag (in memorian) pelo incentivo ao estudo com nutrição mineral de plantas.

A todos os professores do Curso de Solos e Nutrição de Plantas pela dedicação e conhecimentos transmitidos.

Aos estagiários de Nutrição Mineral de Plantas pela ajuda, dedicação e amizade.

Aos funcionários do laboratório de Nutrição Mineral de Plantas Edinéia Cristina Scervino Mandoni, Fernando Éder Ré, Lúcia Helena S. P. Forti, Lurdes Aparecida Dário de González, Mirtes Ventura Sesso, Nivanda Maria de Moura, Sueli Maria Amaral Campos Bovi e Giovana Maria de Oliveira pelo apoio à realização das análises.

Aos companheiros de curso e amigos, especialmente Ana Aparecida da Silva, Anacleto Ranulfo dos Santos, Beatriz Dias Corrêa, Itamar Gislon, João Batista Rodrigues de Abreu, Júlio César Raposo de Almeida e Renata Aparecida Martim pelo carinho, ajuda e incentivo.

Ao $\mathrm{CNPq}$ pelo apoio financeiro e institucional prestado para a realização deste trabalho. 


\section{SUMÁRIO}

Página

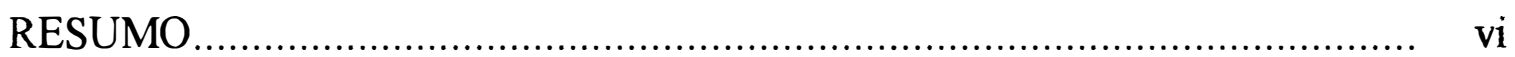

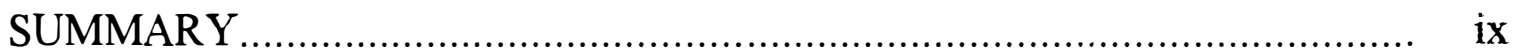

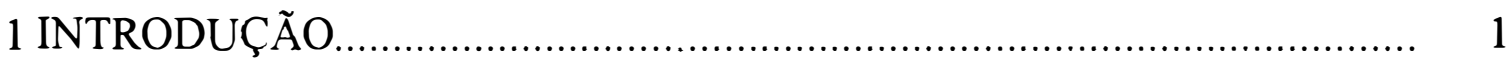

2 REVISÃO DE LITERATURA...................................................... 3

2.10 gênero Brachiaria .......................................................................... 3

2.2 Potássio em gramíneas forrageiras......................................................... 5

2.3 Amostragem de gramíneas forrageiras para diagnose foliar..................... 12

2.4 Níveis críticos em gramíneas forrageiras................................................ 15

3 MATERIAL E MÉTODOS ......................................................... 17

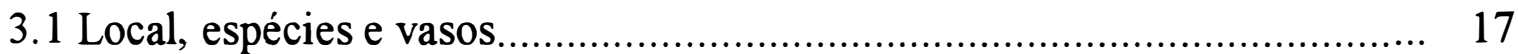

3.2 Tratamentos, soluções nutritivas e delineamento experimental................. 17

3.3 Condução dos experimentos e coleta do material vegetal.......................... 19

3.3.1 Experimento com Brachiaria decumbens Stapf. cv. Basilisk................. 19

3.3.2 Experimento com Brachiaria brizantha (Hochst ex A.Rich.) Stapf. cv.

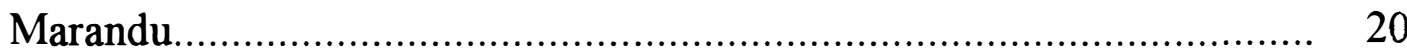

3.4 Determinações no material vegetal........................................................ 21

3.4.1 Produção de matéria seca.................................................................. 21

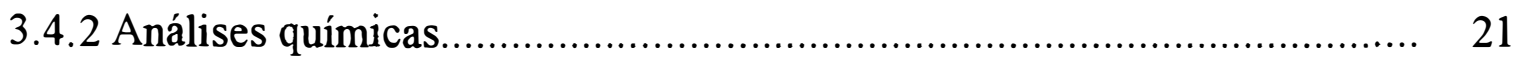

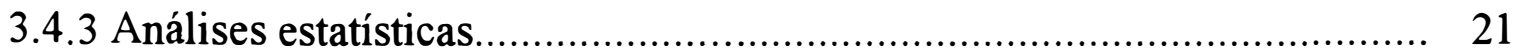

4 RESULTADOS E DISCUSSÃO ……………................................ 23

4.1 Experimento com a Brachiaria decumbens Stapf. cv. Basilisk.................. 23

4.1.1 Produção de matéria seca da parte aérea e das raízes............................... 23

4.1.2 Número de perfilhos....................................................................... 26 
4.1.3 Concentração de potássio nos tecidos vegetais....................................... 28

4.1.3.1 Folhas não-expandidas.................................................................. 28

4.1.3.2 Lâminas de folhas novas............................................................ 31

4.1.3.3 Lâminas de folhas velhas................................................................. 33

4.1.3.4. Colmos mais bainhas................................................................... 35

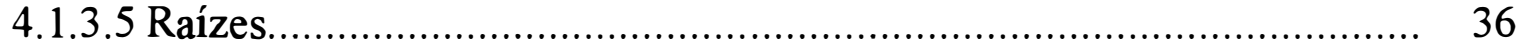

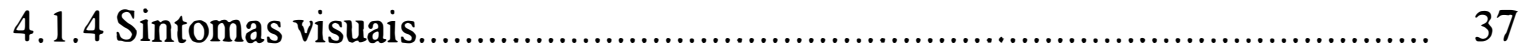

4.1.5 Distribuição do potássio na parte aérea................................................. 39

4.1.6 Níveis críticos de potássio................................................................. 40

4.2 Experimento com a Brachiaria brizantha (Hochst ex A.Rich.) Stapf. cv.

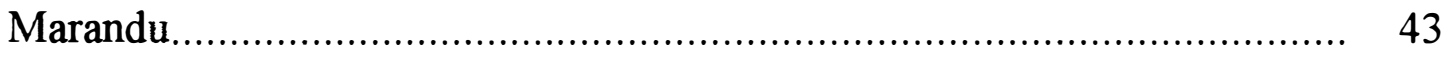

4.2.1 Produção de matéria seca da parte aérea e das raízes.............................. 43

4.2.2 Núrnero de perfilhos...................................................................... 46

4.2.3 Concentração de potássio nos tecidos vegetais...................................... 48

4.2.3.1 Folhas não-expandidas................................................................. 48

4.2.3.2 Lâminas de folhas novas............................................................. 50

4.2.3.3 Lâminas de folhas velhas................................................................. 52

4.2.3.4 Colmos mais bainhas.................................................................... 54

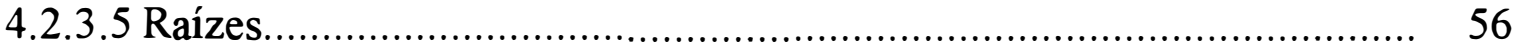

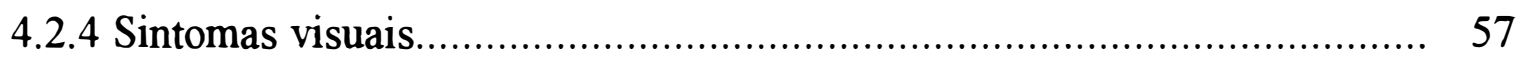

4.2.5 Distribuição do potássio na parte aérea............................................... 59

4.2.6 Níveis críticos de potássio................................................................... 60

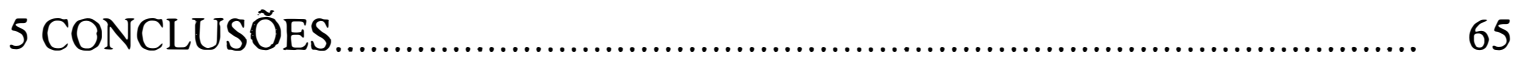

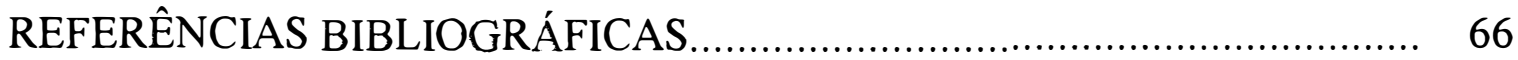




\title{
DIAGNOSE NUTRICIONAL DE POTÁSSIO EM DUAS ESPÉCIES DE BRAQUIÁRIA
}

\author{
Autor: Waldssimiler Teixeira de Mattos \\ Orientador: Prof. Dr. Francisco Antonio Monteiro
}

\section{RESUMO}

Foram conduzidos dois experimentos em casa-de-vegetação com solução nutritiva envolvendo as espécies forrageiras Brachiaria decumbens Stapf. cv. Basilisk e Brachiaria brizantha (Hochst ex A.Rich.) Stapf. cv. Marandu. No primeiro experimento as plantas de $B$. decumbens foram cultivadas de agosto a novembro de 1996, enquanto no segundo experimento as de B. brizantha foram cultivadas de dezembro de 1996 a fevereiro de 1997, com o objetivo de avaliar o efeito das doses de potássio na produção de matéria seca, perfilhamento, concentração de potássio na planta, de selecionar a parte dessas forrageiras que melhor caracterize o estado nutricional no que diz respeito ao potássio e determinar os níveis críticos de potássio na parte amostrada desses capins.

Foram utilizadas oito doses de potássio $(0 ; 9,75 ; 39 ; 78 ; 156 ; 234 ; 312$ e 468

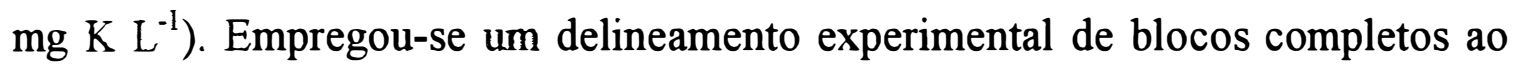
acaso, com quatro repetições. Procurando atender a quantidade necessária de material vegetal para análises químicas, tratou-se de duplicar cada parcela correspondente às amostragens. Assim, foram utilizados oito vasos para cada dose 
do nutriente estudado, em cada um dos experimentos. As plantas foram colhidas 38 e 71 dias após o transplante, para o primeiro e segundo cortes, sendo separadas em folhas não-expandidas, lâminas de folhas novas, lâminas de folhas velhas e colmos + bainhas. Por ocasião do segundo corte foram também coletadas as raízes.

Os resultados mostraram efeitos significativos das doses de potássio na produção de matéria seca da parte aérea e das raízes, no número de perfilhos e na concentração de potássio nos tecidos. A máxima produção de matéria seca na Brachiaria decumbens Stapf. cv. Basilisk ocorreria com doses de potássio entre 445 e $531 \mathrm{mg} \mathrm{K} \mathrm{L}^{-1}$. No experimento com a Brachiaria brizantha (Hochst ex A.Rich.) Stapf. cv. Marandu os valores máximos de produção de matéria seca foram atingidos com doses de potássio entre 365 e $399 \mathrm{mg} \mathrm{K} \mathrm{L} \mathrm{L}^{-1}$. Foram evidentes as diferenças nas concentrações de potássio entre as partes amostradas das plantas em ambos os experimentos.

Sintomas visuais de deficiência de potássio ocorreram nas plantas cultivadas na solução que não recebeu potássio. Também foram observados sintomas de deficiência do nutriente nas plantas crescidas nas doses inferiores a $78 \mathrm{mg} \mathrm{L}^{-1}$ de potássio na solução.

Os níveis críticos de potássio ocorreram entre 20 e $23 \mathrm{~g} \mathrm{~kg}^{-1}$ nas lâminas de folhas novas na Brachiaria decumbens Stapf. cv. Basilisk. Para a Brachiaria brizantha (Hochst A.Rich.) Stapf. cv. Marandu, os níveis críticos variaram na 
faixa de 22 a $29 \mathrm{~g} \mathrm{~kg}^{-1}$ nas lâminas de folhas novas. Recomenda-se o uso das lâminas de folhas novas como a parte da planta para fins de diagnose nutricional da Brachiaria decumbens Stapf. cv. Basilisk e da Brachiaria brizantha (Hochst ex A.Rich.) Stapf. cv. Marandu quanto ao potássio. 


\title{
POTASSIUM DIAGNOSIS IN TWO BRACHIARIA SPECIES
}

\author{
Author: Waldssimiler Teixeira de Mattos \\ Adviser: Prof. Dr. Francisco Antonio Monteiro
}

\section{SUMMARY}

Two greenhouse experiments were carried out in nutrient solution with the forages Brachiaria decumbens Stapf. cv. Basilisk and Brachiaria brizantha (Hochst ex A.Rich.) Stapf. cv. Marandu. In the first experiment the grass $B$. decumbens was grown from August to November of 1996 and in the second experiment the forage B. brizantha was grown from December of 1996 to February of 1997. The objective was to evaluate the effects of potassium rates on dry matter yield, tiller number, potassium concentration in the plant, to select the part of the forage to be sampled and to determine the critical level for potassium in the plant part sampled from the forage.

Eight levels of potassium $\left(0 ; 9.75 ; 39 ; 78 ; 156 ; 234 ; 312\right.$ and $\left.468 \mathrm{mg} \mathrm{K} \mathrm{L}^{-1}\right)$ were tested. The experiments were set in complete randomized block designs, with four replications. Plants were harvested at 38 and 71 days after transplanting for the first and second growth periods, and plant tops were separated into non-expanded leaves, young leaf blades, old leaf blades and stems + sheaths and roots. 
The results showed significant effects for potassium rates on total dry matter yield, on tiller number and potassium concentration in the plant tissue. Maximum dry matter yield in Brachiaria decumbens Stapf. cv. Basilisk should be attained with potassium rates between 445 and $531 \mathrm{mg} \mathrm{K} \mathrm{L}^{-1}$. In Brachiaria brizantha (Hochst ex. A.Rich.) Stapf. cv. Marandu experiment maximum values for forage yield were attained with potassium rates between 365 and $399 \mathrm{mg} \mathrm{K}$ $\mathrm{L}^{-1}$. Differences in potassium concentration were evident among the sampled plant parts.

Visual symptoms of potassium deficiency were observed in plants grown in the no-potassium solution and also in plants grown at rates lower than $78 \mathrm{mg} \mathrm{K}$ $\mathrm{L}^{-1}$

Critical potassium levels in plant tissue were set between 20 and $23 \mathrm{~g}$ $\mathrm{kg}^{-1}$ in young leaf blades of Brachiaria decumbens Stapf. cv. Basilisk. For Brachiaria brizantha (Hochst A.Rich.) Stapf. cv. Marandu, the critical levels were in the range of 22 and $29 \mathrm{~g} \mathrm{~kg}^{-1}$ in young leaf blades. The use of the young leaf blades for tissue analysis purposes in the potassium diagnosis in Brachiaria decumbens Stapf. cv. Basilisk and Brachiaria brizantha (Hochst ex A.Rich.) Stapf. cv. Marandu is recommended. 


\section{INTRODUÇÃO}

Nas condições brasileiras é possivel explorar técnica e economicamente a capacidade produtiva de forrageiras de climas tropicais. Entre essas forrageiras podem-se destacar as gramíneas do gênero Brachiaria como sendo de grande importância e atualmente muito utilizadas no Brasil Central.

A baixa fertilidade dos solos nas regiões tropicais é um fato bastante destacado e torna imperiosa a sua consideração em áreas de pastagens. Também, estudos isolados de nutrientes relacionados com a composição mineral de plantas forrageiras têm grande importância no diagnóstico do estado nutricional.

O potássio é um dos elementos que apresenta influência direta na produção de forragem, pois tem papel fundamental no metabolismo vegetal, atuando na fotossíntese, sendo responsável pela translocação dos carboidratos e, ainda funcionando como ativador enzimático. Além disso, sabe-se que o potássio 
tem influência direta na resistência da planta ao ataque de doenças e ao tombamento.

O diagnóstico do estado nutricional nas espécies forrageiras vem sendo uma preocupação não apenas da pesquisa, mas também de setores envolvidos com a atividade pecuária. À medida que o produtor consegue controlar, com eficiência, sua produção ele pode assegurar a lucratividade de seu empreendimento. Nesse sentido, a avaliação do estado nutricional de uma planta requer muito cuidado na seleção da parte da planta que melhor reflita a condição de nutrição do vegetal, com relação ao nutriente estudado e possibilitando a identificação dos níveis críticos dos nutrientes.

Dentro desse contexto procurou-se estudar o comportamento das espécies Brachiaria brizantha (Hochst ex A.Rich.) Stapf. cv. Marandu e Brachiaria decumbens Stapf. cv. Basilisk submetidas a doses de potássio, quanto à produção de matéria seca, perfilhamento, bem como determinar a concentração de potássio na planta, selecionar a(s) parte(s) dessas forrageiras que melhor caracterize $(m)$ o seu estado nutricional no que diz respeito ao potássio e procurar determinar os níveis críticos de potássio nas partes amostradas dessas forrageiras. 


\section{REVISÃO DE LITERATURA}

\subsection{O gênero Brachiaria}

Gramíneas do gênero Brachiaria têm seu principal centro de origem e diversificação no leste da África e ocorrem naturalmente nas savanas africanas (IBPGR, 1984). O gênero compreende cerca de 90 espécies de grande diversidade morfológica e fenológica (Clayton \& Renvoize, 1982). As gramineas desse gênero se reproduzem por apomixia, sendo desnecessário isolar culturas para a produção de sementes (Pritchard, 1967). Estima-se que pastagens de braquiária cubram mais de 40 milhões de hectares no Brasil (Censo Agropecuário, 1985) e duas espécies, Brachiaria decumbens cv. Basilisk e Brachiaria brizantha cv. Marandu, representam mais de $85 \%$ desta área.

A Brachiaria decumbens Stapf. é uma espécie perene que ocorre de forma nativa no leste tropical da África (do Equador aos paralelos $30^{\circ} \mathrm{N}$ e S) em 
altitudes acima de $800 \mathrm{~m}$, sob clima moderadamente úmido, em pastagens abertas ou em áreas com arbustos esporádicos (Bogdan, 1977).

O cultivar Basilisk foi trazido para São Paulo em 1970, proveniente da Austrália, mas é de origem africana (Alcântara, 1986). Segundo Ghisi \& Pedreira (1986) a implantação de áreas de pastagens com a Brachiaria decumbens Stapf. cv. Basilisk deu-se de maneira acentuada, devido a boa produção e germinação de sementes, além de outras qualidades agronômicas.

A Brachiaria brizantha cv. Marandu é uma espécie perene originária de uma região vulcânica da África tropical, onde os solos geralmente apresentam bons níveis de fertilidade (Bogdan, 1977).

O cultivar Marandu é um ecotipo de Brachiaria brizantha que foi cultivada por vários anos em Ibirarema, São Paulo, de onde foi distribuído a várias regiões. Em 1977 esta gramínea foi formecida ao Centro Nacional de Pesquisa de Gado de Corte (CNPGC-EMBRAPA), em Campo Grande, tendo sido incluída no processo de avaliação de forrageiras. O Centro de Pesquisa Agropecuária dos Cerrados (CPAC-EMBRAPA), em Planaltina, recebeu esse cultivar em 1979. Após alguns anos de estudos, os dois centros de pesquisa lançaram este cultivar em 1984, como mais uma alternativa para diversificação das áreas de pastagens (Nunes et al., 1985).

A Brachiaria brizantha cv. Marandu é recomendada para cerrados de média a boa fertilidade, tolerando condições moderadas de acidez no solo. Tem 
mostrado bom valor forrageiro, alta produção de massa verde e alta produção de sementes viáveis (Soares Filho, 1994).

\subsection{Potássio em gramíneas forrageiras}

Dentre os macronutrientes o potássio normalmente ocupa o segundo lugar em quantidade extraída pelas plantas. Ele tem ação fundamental no metabolismo vegetal, pelo papel que exerce na fotossíntese, sendo também responsável pela translocação dos carboidratos sintetizados no processo fotossintético e ativador enzimático (Epstein, 1975).

O potássio é absorvido pelas plantas como $\mathrm{K}^{+}$e o nutriente mantém-se na planta sempre nesta forma. O potássio é extremamente móvel na planta, ocorrendo o seu transporte a longas distâncias. Na deficiência de potássio inicialmente só ocorre redução de crescimento e, apenas em fases mais avançadas da deficiência, ocorre clorose e necrose das folhas. Os sintomas de carência começam, em geral, nas folhas mais velhas, já que estas suprem esse nutriente para as mais novas. A clorose, seguida de necrose, ocorre nas pontas e nas margens das folhas (Raij, 1991).

Vicente-Chandler et al. (1962) cultivaram capim-colonião em solo Podzólico Vermelho-Amarelo, sob regime de cortes mecânicos com elevada dose de nitrogênio. Os autores forneceram potássio, em seis aplicações por ano, nas 
doses de $0 ; 220 ; 440 ; 880$ e $1760 \mathrm{~kg} \mathrm{ha}^{-1}$. Constataram efeito positivo na produção de matéria seca da forrageira em aplicações de potássio de até $440 \mathrm{~kg} \mathrm{ha}^{-1} \mathrm{ano}^{-1} \mathrm{e}$, no local onde não recebeu essa adubação a gramínea apresentou sintomas de deficiência de potássio, como pontos marrons e necrose na ponta das folhas mais velhas.

Monteiro et al. (1980) estudaram o efeito da adubação potássica em capim-colonião (Panicum maximum) submetido também a níveis de nitrogênio, no capim consorciado com leguminosas e em leguminosas em cultivo exclusivo. O teor de potássio no solo era baixo no início do experimento. No período experimental de um ano, verificaram que a adubação potássica proporcionou aumentos significativos na produção de matéria seca e na concentração desse nutriente no capim. Acrescentaram também que é necessária a aplicação contínua e abundante de adubo que contenha potássio, para evitar o mascaramento da resposta do capim ao nitrogênio.

Raij \& Quaggio (1984) realizaram experimento em vasos para verificar a disponibilidade de potássio em alguns solos do Estado de São Paulo, para a Brachiaria decumbens. Analisaram o potássio trocável no solo no início e no final do experimento e determinaram o potássio absorvido pela parte aérea da forrageira. Os autores relataram que a diminuição do teor de potássio trocável no solo foi inferior à quantidade de potássio absorvida pela planta, o que realmente mostra haver alguma contribuição de formas não trocáveis do solo e que este fato 
é indicado pela relação entre o potássio absorvido e a diminuição do teor de potássio trocável, que foi, em geral maior do que um.

Mesa et al. (1989) trabalharam com níveis de potássio variando entre 0 e $400 \mathrm{~kg} \mathrm{ha}^{-1}$ para o Panicum maximum cv. Likoni, Cenchrus ciliaris cv. formidable, Cynodon dactylon cv. 68 e Chloris gayana cv. Callide. Verificaram aumento significativo na produção de matéria seca quando o potássio atingiu dose até $50 \mathrm{~kg} \mathrm{ha}^{-1}$ para Bermuda 68, Likoni e Rhodes callide, enquanto que para o Buffel formidable o aumento significativo foi até $150 \mathrm{~kg} \mathrm{ha}^{-1}$.

Carvalho et al. (1991) conduziram um experimento de campo, por dois anos, em um Latossolo Vermelho-Amarelo álico, onde estudaram o efeito de aplicação de nitrogênio e potássio sobre a produtividade da Brachiaria decumbens Stapf, em regime de cortes. Os autores forneceram três doses de potássio, na forma de $\mathrm{KCl}, 0,75$, e $150 \mathrm{~kg} \mathrm{de}_{2} \mathrm{O} \mathrm{ha}^{-1} \mathrm{ano}^{-1}$, para o primeiro ano e 50, 100 e $200 \mathrm{~kg} \mathrm{~K}_{2} \mathrm{O} \mathrm{ha}^{-1} \mathrm{ano}^{-1}$ para o segundo ano. Constataram que, com baixa dose de potássio, desenvolveram-se sintomas de deficiência do nutriente nas folhas, porém na ausência desses sintomas, as concentrações de potássio, na parte aérea, ficaram entre 10 e $15 \mathrm{~g} \mathrm{~kg}^{-1}$.

Silva et al. (1995) cultivaram o capim-Tanzânia sob sete níveis de potássio ( $0 ; 9,75 ; 39 ; 78 ; 156 ; 234$ e $312 \mathrm{mg} \mathrm{L}^{-1}$ de solução) e puderam verificar respostas positivas ao potássio, em termos de perfilhamento e produção de matéria seca das folhas novas e de toda parte aérea do capim. Também 
observaram que as produções máximas ocorreriam em níveis superiores aos utilizados e que a produção de folhas velhas e de colmos + bainhas apresentaram respostas lineares às doses de potássio na solução.

Monteiro et al. (1995), em experimento de nutrição mineral de omissão de nutrientes utilizando a Brachiaria brizantha cv. Marandu, relataram que a omissão de potássio na solução nutritiva não resultou em redução significativa na produção de matéria seca e no perfilhamento, quando comparada ao tratamento completo. Entretanto, para os teores de potássio, observaram que $4,3 \mathrm{~g} \mathrm{~kg}^{-1}$ na parte aérea e $3,6 \mathrm{~g} \mathrm{~kg}^{-1}$ nas raízes foram significativamente mais baixos do que nas plantas do tratamento completo, onde os teores foram de 28,0 e $25,0 \mathrm{~g} \mathrm{~kg}^{-1}$, respectivamente. Sintomas de deficiência de potássio foram observados a partir da terceira semana após o transplante, com as plantas apresentando folhas mais estreitas e necrose nas margens das lâminas foliares.

Conduzindo experimento com doses de potássio de $0 ; 50 ; 100 ; 200$ e 400 $\mathrm{mg}$ de $\mathrm{K} \mathrm{kg}^{-1}$ de solo para braquiária (Brachiaria decumbens Stapf.) e colonião (Panicum maximum Jacq.), Faquin et al. (1995) verificaram aumentos significativos na produção de matéria seca da parte aérea das forrageiras, nos dois cortes e no total dos cortes, cujas equações de regressão mostraram uma relação quadrática para as doses de potássio, para ambas as espécies. O efeito das doses de potássio não foi suficiente para promover diferenças significativas no perfilhamento do colonião, enquanto, na braquiária a significância foi verificada. 
Werner \& Haag (1972) verificaram, no capim-colonião, um teor adequado de potássio nas folhas de $18,4 \mathrm{~g} \mathrm{~kg}^{-1}$ e para os colmos de $29,6 \mathrm{~g} \mathrm{~kg}^{-1}$. Para o capim-colonião, Toledo (1984) determinou $11,5 \mathrm{~g} \mathrm{~kg}^{-1}$ de $\mathrm{K}$ como o teor adequado na matéria seca da parte aérea. Carriel et al. (1989) e Ferrari Neto (1991) encontraram 11,0 e $10,0 \mathrm{~g} \mathrm{~kg}^{-1}$ e 10,5 e $11,0 \mathrm{~g} \mathrm{~kg}^{-1}$ de $\mathrm{K}$, para a parte aérea do capim-colonião e braquiária decumbens respectivamente.

Gonzalez et al. (1983) observaram diferença significativa entre o teor médio de potássio obtido no Coastal (Cynodon dactylon) $\left(12,0 \mathrm{~g} \mathrm{~kg}^{-1}\right)$ e aquele do Coastcross 1 (Cynodon dactylon) (14,8 $\left.\mathrm{g} \mathrm{kg}^{-1}\right)$, utilizando uma adubação básica de potássio de $83 \mathrm{~kg}$ de $\mathrm{K} \mathrm{ha}^{-1}$. Gomide et al. (1969) encontraram em Cynodon dactylon cv. Swannee um teor médio de potássio de $11,7 \mathrm{~g} \mathrm{~kg}^{-1}$, na ausência de adubação. Segundo Hernández \& Cárdenas (1990) o teor máximo de potássio encontrado no capim-estrela (Cynodon nlemfuensis cv. jamaicano) foi de 19,7 g $\mathrm{kg}^{-1}$, quando a adubação potássica aplicada foi de $165 \mathrm{~kg}$ de $\mathrm{K} \mathrm{ha}^{-1}$. O valor médio de potássio nos capins-bermuda Cynodon dactylon cv Alicia e Cynodon dactylon cv. Coastal foi de $17,8 \mathrm{~g} \mathrm{~kg}^{-1}$, quando adubados com $115 \mathrm{~kg}$ de $\mathrm{K} \mathrm{ha}^{-1}$ durante a estação de crescimento e com amostragens feitas a cada duas semanas (Kappel et al., 1985).

Eichhorn Junior \& Hallmark (1989) observaram que a produção de matéria seca de Coastal decresceu quando a concentração de potássio foi menor que $22,4 \mathrm{~g} \mathrm{~kg}^{-1}$. Cripps et al. (1989) cultivaram o capim Coastal em um solo 
arenoso aplicando quatro doses de potássio $\left(0,140,279 \mathrm{e}^{2} 19 \mathrm{~kg} \mathrm{~K} \mathrm{ha}^{-1} \mathrm{ano}^{-1}\right) \mathrm{e}$ seis doses de calcário $\left(0 ; 2,2 ; 3,6 ; 4,5 ; 9,0\right.$ e $\left.18,0 \mathrm{Mg} \mathrm{ha}^{-1}\right)$. Os autores obtiveram máxima produção quando a concentração de potássio nos tecidos desse capim foi de $22,0 \mathrm{~g} \mathrm{~kg}^{-1}$. No Brasil, o teor médio de potássio encontrado em amostras de pastagens de Cynodon dactylon no Estado de São Paulo foi de $18,8 \mathrm{~g} \mathrm{~kg}^{-1}$ (Gallo et al., 1974). França \& Haag (1985) trabalhando com o capim-tobiatã, em condições controladas, utilizando soluções nutritivas completa e com omissão de nutrientes, verificaram que, na omissão do potássio, houve redução acentuada na produção de matéria seca e menor número de perfilhos. Os autores observaram ainda sintomas visuais de deficiência de potássio nesse capim quando o teor nas folhas foi menor do que $4,7 \mathrm{~g} \mathrm{~kg}^{-1}$.

Em estudos com Coastcross 1 (Cynodon dactylon) em solos mal drenados, Bufarah et al. (1982) encontraram teor de potássio de $10,3 \mathrm{~g} \mathrm{~kg}^{-1}$. Palhano (1990) encontrou teor médio para o mesmo capim de $17,0 \mathrm{~g} \mathrm{~kg}^{-1}$ aos 30 dias de crescimento, utilizando adubação de $250 \mathrm{~kg}$ de $\mathrm{K} \mathrm{ha}^{-1}$, e também observou que o teor de potássio na planta diminuiu significativamente com a idade. Gomide et al. (1969) observaram que o teor de potássio diminuiu de 14,2 para 3,0 $\mathrm{g} \mathrm{kg}^{-1}$ com o avanço da idade de quatro para 36 semanas em seis espécies de capins tropicais cultivadas em solo arenoso.

Martim (1997) conduziu um experimento com duas plantas forrageiras, o Tifton 85 e o Coastcross 1, submetendo-as a doses de fertilização nitrogenada e 
potássica num Latossolo Vermelho-Amarelo ácrico. Verificou que a produção de matéria seca da parte aérea dos dois capins foi incrementada pelas doses de potássio no segundo e terceiro cortes, quando foram empregadas as doses mais elevadas de nitrogênio. Para a aplicação das mais elevadas doses de nitrogênio, somente na presença das maiores doses de potássio a produção de matéria seca das raízes foi incrementada nessas forrageiras. O teor de potássio na parte aérea dos capins aumentou linearmente com a adubação potássica no primeiro e segundo crescimento, proporcionando nos capins uma variação de 13,4 para 17,4 $\mathrm{g} \mathrm{kg}^{-1}$ e de 3,7 para $13,3 \mathrm{~g} \mathrm{~kg}^{-1}$, respectivamente representando aumentos de $30 \mathrm{e}$ $259 \%$ no primeiro e segundo cortes. No terceiro crescimento o Tifton 85 e o Coastcross 1, apesar de apresentarem aumentos na produção de matéria seca com as doses de potássio, não mostraram aumentos na concentração de potássio nos tecidos. Os sintomas de deficiência de potássio apareceram no tratamento com a menor dose de potássio e foram observados a partir do primeiro crescimento em Coastcross 1 e do segundo crescimento em Tifton 85 .

Diante dessas informações fica evidente a carência de trabalhos com potássio em braquiárias, o que faz com que pesquisadores e produtores não conheçam as verdadeiras exigências desses capins com relação a esse nutriente. 


\subsection{Amostragem de gramíneas forrageiras para diagnose foliar}

A diagnose foliar pode ser feita por meio da observação visual de sintomas de distúrbios nutricionais ou através de outros procedimentos envolvendo por exemplo a análise química das folhas. Em ambos os casos há necessidade de serem observados determinados princípios para que os resultados possam ser devidamente interpretados e conduzam a recomendações com resultados econômicos para os produtores (Bataglia et al., 1995).

As folhas são o órgão onde ocorre a maior parte das atividades fisiológicas nas plantas. Alterações na nutrição mineral são de certa forma refletidas nas concentrações dos nutrientes nas folhas. A utilização da análise foliar como critério diagnóstico baseia-se na premissa de existir relação entre o suprimento de nutrientes no substrato e os níveis dos elementos no tecido foliar, e que aumentos ou diminuições nas concentrações se relacionem com produções mais altas ou mais baixas, respectivamente (Evenhuis \& Waard, 1980).

Jones \& Steyn (1973) apontaram que uma parte específica da planta deve ser selecionada na amostragem para análise de tecidos e que essa parte selecionada deve corresponder às melhores relações que existem entre $a \rightarrow$ concentração do nutriente e a produção da planta. 
Martim \& Matocha (1973) enfatizaram que a parte da planta a ser amostrada deve refletir com precisão o estado nutricional da planta, apresentar uma amplitude de concentração desde a deficiência até a adequação, ser simples para amostrar, possuir um nível crítico relativamente constante em sucessivas amostragens e deve ser de fácil identificação e coleta no campo.

De acordo com Smith (1962) analisar a planta toda pode ocasionar dúvida quanto a confiabilidade dos resultados, devido à presença de nutrientes minerais em tecidos inativos, que podem esconder diferenças funcionais. $\mathrm{O}$ autor ainda mencionou que a folha é o tecido mais prático para uso geral na amostragem, mas para alguns nutrientes outras partes da planta podem ser indicadoras mais sensíveis.

Em estudo relativo à diagnose nutricional de fósforo na Brachiaria decumbens, Monteiro et al. (1995) amostraram as folhas não-expandidas, as lâminas de folhas novas, as lâminas de folhas velhas e os colmos + bainhas. Posteriormente, Monteiro et al. (1997) empregaram o mesmo sistema de amostragem para Brachiaria brizantha cv. Marandu, também, em estudo de diagnose de fósforo.

Realizando estudo para diagnóstico de potássio no capim-Tanzânia-1 Mattos et al. (1996) amostraram separadamente as folhas não-expandidas + lâminas de folhas novas, as lâminas de folhas velhas e colmos + bainhas. 
Em estudo relativo à concentração de nitrogênio no capim-Vencedor, Corrêa et al. (1996) amostraram as folhas não-expandidas + lâminas de folhas novas, as lâminas de folhas velhas e colmos + bainhas.

Corrêa (1996) em um estudo com solução nutritiva utilizando os cultivares Colonião, Tanzânia-1 e Vencedor de Panicum maximum Jacq. submetidos a três doses de nitrogênio $\left(42 ; 210\right.$ e $\left.378 \mathrm{mg} \mathrm{de} \mathrm{N} \mathrm{L}^{-1}\right)$ e duas doses de magnésio (4,8 e $48 \mathrm{mg}$ de $\left.\mathrm{Mg} \mathrm{L}^{-1}\right)$, amostrou a parte aérea da planta separada em folhas não-expandidas + lâminas de folhas novas, lâminas de folhas velhas e colmos + bainhas.

Martim (1997), em estudo o com os capins Tifton 85 e Coastcross 1 submetidos a doses de nitrogênio e de potássio em um Latossolo VermelhoAmarelo ácrico , amostrou, para fins de diagnose, as lâminas foliares separadamente da hastes + bainhas.

Abreu (1994) conduziu dois experimentos com solução nutritiva envolvendo as gramíneas forrageiras Panicum maximum Jacq. cv. Tanzânia-1, Brachiaria braizantha cv. Marandu e Melinis minutiflora Beauv. das quais foram coletadas a parte aérea e separadas em folhas não-expandidas + lâminas de folhas novas, lâminas de folhas velhas e colmos + bainhas para fins de diagnose foliar.

Faquin et al. (1995), procedendo à amostragem para fins de diagnose foliar de potássio e de enxofre em Brachiaria decumbens Stapf. e Panicum 
maximum Jacq., coletou folhas com lâmina totalmente expandida e com lígula visível, separadamente do restante do material vegetal da parte aérea.

\subsection{Níveis críticos em gramíneas forrageiras}

O nível crítico corresponde à concentração na folha abaixo do qual a taxa de crescimento, a produção ou a qualidade são significativamente diminuídas.

Ulrich \& Hills (1967) estabeleceram que o nível crítico, para diversas culturas, é a concentração correspondente a uma produção de $95 \%$ da ótima, enquanto Gallo et al. (1965) estabeleceram níveis críticos para milho com base numa produção relativa de $80 \%$.

Num conceito interpretativo desenvolvido por Okhi (1987), o nível crítico do nutriente é a concentração que provoca uma redução de $10 \%$ na produção máxima. Esse nível é definido como nível crítico de deficiência. De forma semelhante, o nível crítico de toxidez é a concentração tóxica do nutriente que reduz em $10 \%$ a produção máxima da planta. Ainda, Ulrich \& Hills (1973) utilizaram, na abordagem de níveis críticos em beterraba açucareira, a concentração associada a uma redução de $10 \%$ na produção como sendo o nível crítico do nutriente. 
Faquin et al. (1995) verificaram que os níveis críticos de potássio na parte aérea do primeiro corte, correspondentes a 80 e $90 \%$ da produção máxima, foram, respectivamente, 11,2 e $13,5 \mathrm{~g} \mathrm{~kg}^{-1}$ para a braquiária e $12,1 \mathrm{e} 14,5 \mathrm{~g} \mathrm{~kg}^{-1}$ para o colonião. Salinas \& Gualdrón (1988) determinaram valores de níveis críticos de potássio na matéria seca da parte aérea da braquiária humidicola no valor de $8,3 \mathrm{~g} \mathrm{~kg}^{-1}$, para $80 \%$ da produção máxima. Carvalho et al. (1991) determinaram valores de níveis críticos de potássio na matéria seca da parte aérea da braquiária na faixa de 10,0 a $15,0 \mathrm{~g} \mathrm{~kg}^{-1}$.

Mesa et al. (1989) consideraram 30,$9 ; 36,4 ; 34,3$ e $33,7 \mathrm{~g} \mathrm{~kg}^{-1}$ como níveis críticos do potássio nas gramíneas Buffel formidable, Bermuda 68, Likoni e Rhodes callide. O nível crítico de potássio em Coastcross 1 encontrado por Gonzalez \& Oilda (1982) foi de 26,0 $\mathrm{g} \mathrm{kg}^{-1}$.

Os níveis críticos de potássio reportados por Martim \& Matocha (1973) para Coastal bermuda e na bermuda Comum foram de 1,5 a $1,7 \mathrm{~g} \mathrm{~kg}^{-1}$ e 1,6 e 1,8 $\mathrm{g} \mathrm{kg}^{-1}$, respectivamente. 


\section{MATERIAL E MÉTODOS}

\subsection{Local, espécies e vasos}

Dois experimentos foram desenvolvidos em casa-de-vegetação localizada na área de Nutrição Mineral de Plantas, Departamento de Química, da Escola Superior de Agricultura "Luiz de Queiroz"- USP, situada em Piracicaba, São Paulo, cultivando-se separadamente a Brachiaria decumbens Stapf. cv. Basilisk e a Brachiaria brizantha (Hochst ex A.Rich.) Stapf. cv. Marandu.

Vasos plásticos com volume de 3,6 L foram preenchidos com sílica e receberam soluções nutritivas correspondentes a cada tratamento, as quais foram circuladas através do substrato duas vezes por dia e foi mantidas nos vasos durante o dia e drenadas à noite. As soluções nutritivas foram trocadas a cada quinze dias.

\subsection{Tratamentos, soluções nutritivas e delineamento experimental}

Foram utilizadas oito doses de potássio correspondentes a $0 ; 9,75 ; 39$; 78; 156; 234; 312 e $468 \mathrm{mg}$ de $\mathrm{K} \mathrm{L}^{-1}$. As soluções foram preparadas a partir daquela proposta por Sarruge (1975), devidamente modificada para satisfazer o suprimento de potássio. A forma como foi preparada a solução de cada tratamento é mostrada na tabela 1 . 


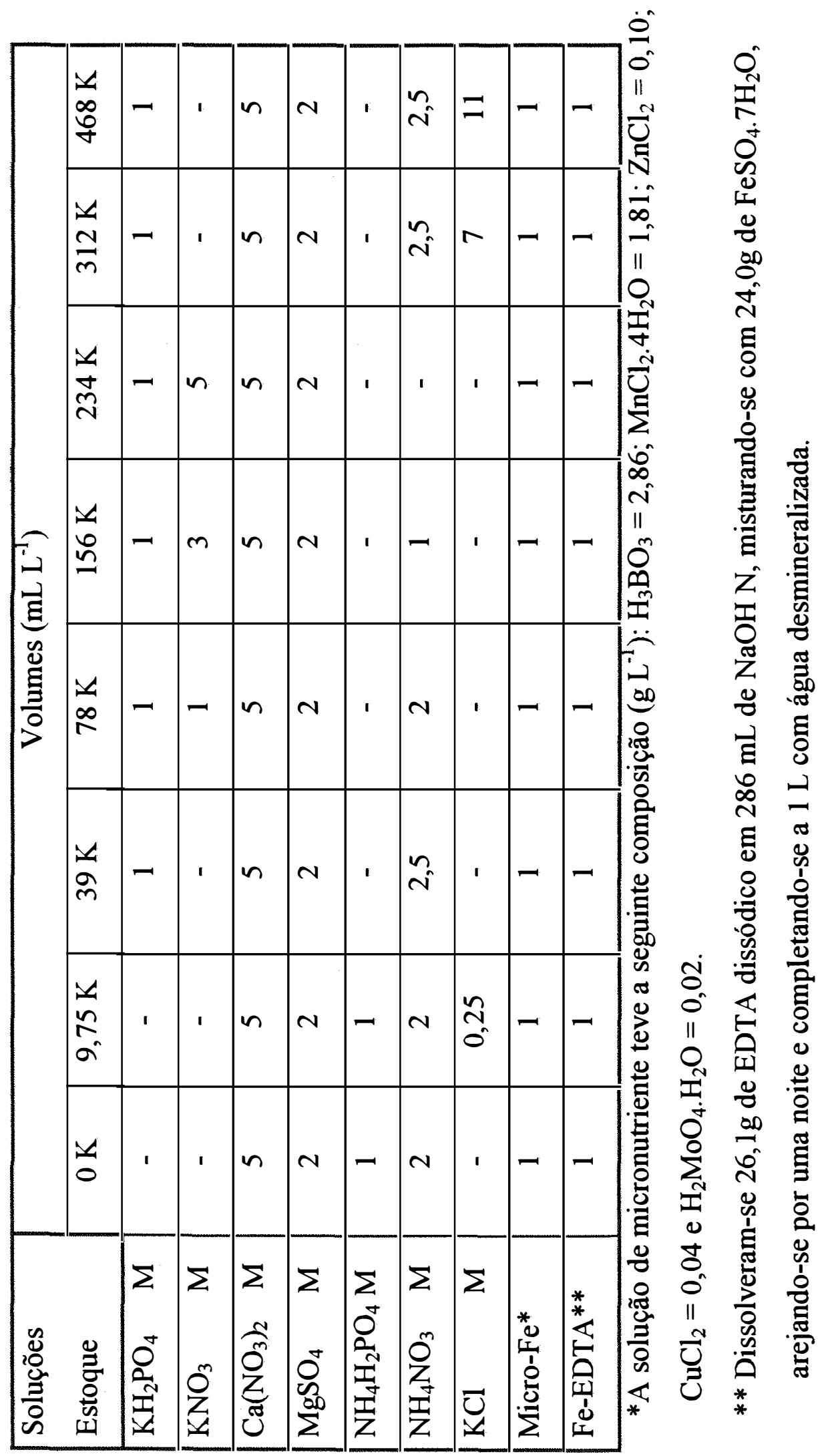


Empregou-se um delineamento experimental de blocos ao acaso, com quatro repetições. Procurando atender a quantidade necessária de material vegetal para análise químicas, tratou-se de duplicar cada parcela correspondente às amostragens de folhas não-expandidas, lâminas de folhas novas, lâminas de folhas velhas e colmos + bainhas das gramíneas forrageiras. Assim, foram utilizados oito vasos para cada dose do nutriente estudado, em cada um dos tratamentos dos dois experimentos. Desse modo, foram empregados 64 vasos para cada um dos experimentos.

\subsection{Condução dos experimentos e coleta do material vegetal}

\subsubsection{Experimento com Brachiaria decumbens Stapf. cv. Basilisk}

A semeadura da Brachiaria decumbens Stapf. cv. Basilisk foi realizada em 21 de agosto de 1996, colocando-se as sementes para germinar em bandejas plásticas contendo areia lavada. Dez dias após a semeadura, em 31 de agosto de 1996, procedeu-se ao transplante de quinze mudas as quais tinham cerca de 3 centímetros de altura. Executaram-se desbastes periódicos para que cada vaso permanecesse no final com cinco plantas.

Aos 38 dias após o transplante, em 08 de outubro de 1996, foi realizado o primeiro corte e as plantas foram separadas em folhas não-expandidas (folhas do topo da planta, sem lígula visível), lâminas de folhas novas (lâminas das duas folhas mais novas completamente expandidas, com lígula visível), lâminas de folhas velhas (lâminas das demais folhas completamente expandidas, com lígula visível) e colmos + bainhas (colmos propriamente dito mais as bainhas que foram mantidas a eles circundadas). Aos 33 dias após o primeiro corte, em 10 de 
novembro de 1996, realizou-se o segundo corte separando-se a parte aérea segundo o mesmo critério do primeiro corte e lavando-se as raízes retiradas da sílica. Todo o material vegetal foi colocado para secar em estufa de circulação forçada de ar à temperatura de $65^{\circ} \mathrm{C}$, até peso constante.

\subsubsection{Experimento com Brachiaria brizantha (Hochst ex A.Rich.) Stapf. cv. Marandu}

As sementes de Brachiaria brizantha (Hochst ex A.Rich.) Stapf. cv. Marandu foram colocadas para germinar em 09 de dezembro de 1996, em bandejas plásticas contendo areia lavada. Dez dias após a semeadura, em 19 de dezembro de 1996, procedeu-se ao transplante de quinze mudas as quais tinham cerca de 3 centímetros de altura. Realizaram-se desbastes periódicos para que cada vaso permanecesse no final com cinco plantas.

Aos 38 dias após o transplante, em 26 de janeiro de 1997, foi realizado o primeiro corte e as plantas foram separadas em folhas não-expandidas, lâminas de folhas novas, lâminas de folhas velhas e colmos + bainhas. Aos 33 dias após o primeiro corte, em 28 de fevereiro de 1997, realizou-se o segundo corte separando-se a parte aérea segundo o mesmo critério do primeiro corte e lavandose as raízes retiradas da sílica. Todo o material vegetal foi colocado para secar em estufa de circulação forçada de ar à temperatura de $65^{\circ} \mathrm{C}$, até peso constante. 


\subsection{Determinações no material vegetal}

\subsubsection{Produção de matéria seca}

Para a obtenção dos resultados de produção de matéria seca da parte aérea (soma de folhas não-expandidas, lâminas de folhas novas, lâminas de folhas velhas e colmos + bainhas) e das raizes foram anotados diretamente os valores das pesagens dos materiais colhidos, após a secagem em estufa.

\subsubsection{Análises químicas}

Na moagem do material vegetal proveniente dos experimentos juntaramse as amostras colhidas em duplicata nos casos das folhas não-expandidas, lâminas de folhas novas, lâminas de folhas velhas e colmos + bainhas. Em seguida as amostras foram moídas em moinho tipo Wiley e acondicionadas em sacos plásticos.

A determinação das concentrações de potássio em cada fração da parte aérea e nas raízes foi efetuada conforme metodologia descrita por Sarruge \& Haag (1974). A digestão utilizada para a determinação do potássio foi a nítricoperclórica e o método analítico foi a fotometria de chama.

\subsubsection{Análises estatísticas}

Os resultados foram submetidos à análise de variância e no caso do teste F significativo, efetuou-se o estudo das regressões das quais aquelas mostrando significância tiveram suas equações calculadas. 
Foram realizados a análise de regressão para a quantidade de matéria seca, teores de potássio e níveis críticos, bem como teste de comparação de médias (Tukey a 5\%) para o perfilhamento e estudo de correlações entre o teor de potássio nas partes das plantas e a produção de matéria seca da parte aérea, utilizando o programa estatístico SAS-WINDOWS (1989). 


\section{RESULTADOS E DISCUSSÃO}

Os resultados serão apresentados e discutidos separadamente para os experimentos com as espécies Brachiaria decumbens Stapf. cv. Basilisk e Brachiaria brizantha (Hochst ex A.Rich.) Stapf. cv. Marandu.

\subsection{Experimento com a Brachiaria decumbens Stapf. cv. Basilisk}

\subsubsection{Produção de matéria seca da parte aérea e das raízes}

A produção de matéria seca da parte aérea na Brachiaria decumbens Stapf. cv. Basilisk teve aumento significativo $(\mathrm{P}<0,01)$, em função das doses de potássio, tanto para o primeiro como para o segundo corte.

No primeiro corte, a produção da parte aérea da Brachiaria decumbens respondeu às doses de potássio, segundo um modelo quadrático (Figura 1). O ponto de máxima produção da parte aérea ocorreu além do limite estudado, com potássio na solução em $531 \mathrm{mg} \mathrm{L}^{-1}$. 


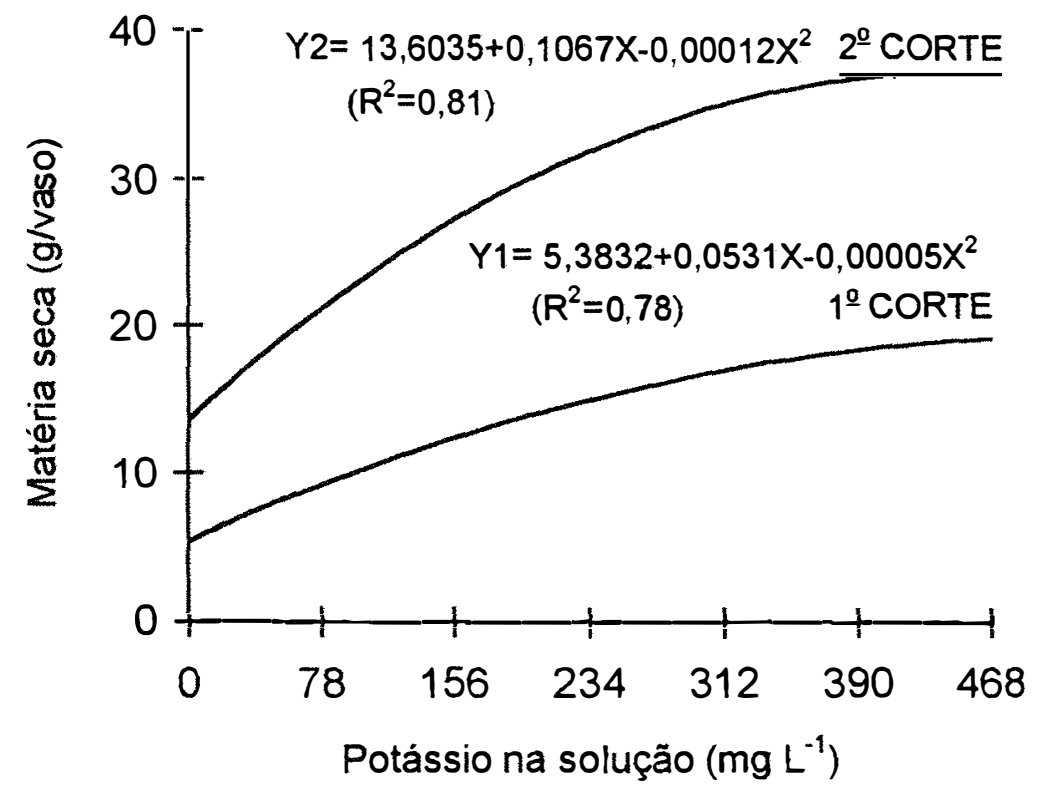

Figura 1 - Produção de matéria seca da parte aérea da Brachiaria decumbens Stapf cv. Basilisk, no primeiro e segundo corte, em função das doses de potássio na solução nutritiva.

No segundo corte, os resultados da produção de matéria seca da parte aérea também ajustaram-se a uma equação do segundo grau (Figura 1). A produção máxima de matéria seca da parte aérea foi obtida com o emprego de 445 $\mathrm{mg} \mathrm{K} \mathrm{L} \mathrm{K}^{-1}$. Faquin et al. (1995) verificaram que o ponto de máxima produção obtido para a Brachiaria decumbens Stapf. foi de $294 \mathrm{mg} \mathrm{K} \mathrm{kg}^{-1}$ de solo, para os dois cortes realizados. Já Silva et al. (1995) para o capim-Tanzânia-1 verificaram que a máxima produção da forrageira ocorreria em torno de $348 \mathrm{mg} \mathrm{K} \mathrm{L}^{-1}$ de solução nutritiva, no primeiro corte da planta.

A produção de matéria seca da parte aérea dessa forrageira revelou incremento em função das doses de potássio, o que concorda com Carvalho et al. 
(1991), os quais verificaram que a produção de matéria seca da parte aérea aumentou significativamente $(\mathrm{P}<0,01)$ com as doses de potássio aplicadas ao solo. Faquin et al. (1995) relataram que as doses aplicadas de potássio influenciaram significativamente $(\mathrm{P}<0,01)$ a produção de matéria seca da parte aérea da braquiária decumbens nos dois cortes realizados, cujas equações de produção mostraram uma relação quadrática com o potássio aplicado. Silva et al. (1995) evidenciaram que a produção de matéria seca da parte aérea do capim-Tanzânia-1 variou significativamente $(P<0,01)$ com a adição de potássio na solução nutritiva. Vicente-Chandler et al. (1962), cultivando capim-colonião, constataram efeito positivo na produção de matéria seca da forrageira em aplicações de potássio de até $440 \mathrm{~kg} \mathrm{ha}^{-1}$ ano $^{-1}$. Monteiro et al. (1980), estudando o efeito da adubação potássica em capim-colonião (Panicum maximum), também verificaram que a aplicação de potássio proporcionou aumentos significativos na produção de matéria seca.

As produções de matéria seca da parte aérea da Brachiaria decumbens Stapf., na dose zero de potássio, representaram cerca de 27,6 e $36,4 \%$ das máximas alcançadas nos dois cortes da planta. Pode-se observar que os valores corresponderam aos obtidos por Ferrari Neto (1991), que na omissão do potássio obteve na adubação 30 e $41 \%$, respectivamente, no primeiro e segundo cortes, da produção de matéria seca da parte aérea daquela obtida no tratamento com adubação completa incluindo potássio. 
A produção de matéria seca das raizes variou significativamente $(\mathrm{P}<0,01)$ com as doses de potássio (Figura 2) e revelou o seu máximo com o emprego de $342 \mathrm{mg} \mathrm{K} \mathrm{L}{ }^{-1}$.

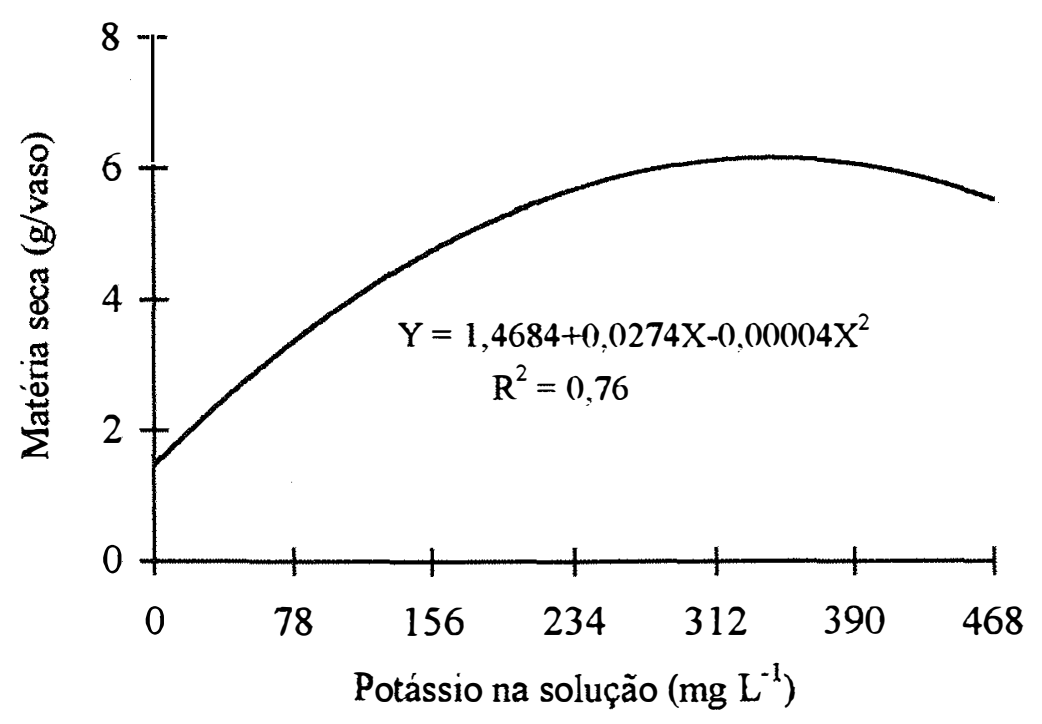

Figura 2 - Produção de matéria seca das raízes da Brachiaria decumbens Stapf. cv. Basilisk, em função das doses de potássio na solução nutritiva.

\subsubsection{Número de perfilhos}

$\mathrm{O}$ número de perfilhos nas cinco plantas foi significativamente $(\mathrm{P}<0,05)$ influenciado pelas doses de potássio, em ambos os crescimentos. Resultados semelhantes foram encontrados por Faquin et al. (1995), que afirmaram ser o número de perfilhos na Brachiaria decumbens Stapf. significativamente influenciado pelas doses de potássio no primeiro corte. Isto sugere que, em espécies com características semelhantes às da braquiária, a fertilização com 
potássio contribuirá para melhor perfilhamento e conseqüentemente maior produção.

No primeiro crescimento o número de perfilhos aumentou significativamente da dose $0 \mathrm{mg} \mathrm{K} \mathrm{L}^{-1}$ para a de $9,75 \mathrm{mg} \mathrm{K} \mathrm{L}^{-1}$ e não variando até a de $156 \mathrm{mg} \mathrm{K} \mathrm{L}^{-1}$. Porém, com relação à dose $9,75 \mathrm{mg} \mathrm{K} \mathrm{L}^{-1}$ o número de perfilhos foi menor do que o obtido nas doses de 234,312 e $468 \mathrm{mg} \mathrm{K} \mathrm{L}^{-1}$ as quais não tiveram variação entre si, no perfilhamento. Por outro lado, nas doses $0 ; 9,75$ e $39 \mathrm{mg} \mathrm{K} \mathrm{L}^{-1}$ foi obtida uma menor quantidade de perfilhos que nas doses de 312 e $468 \mathrm{mg} \mathrm{K} \mathrm{L}^{-1}$ (Figura 3).

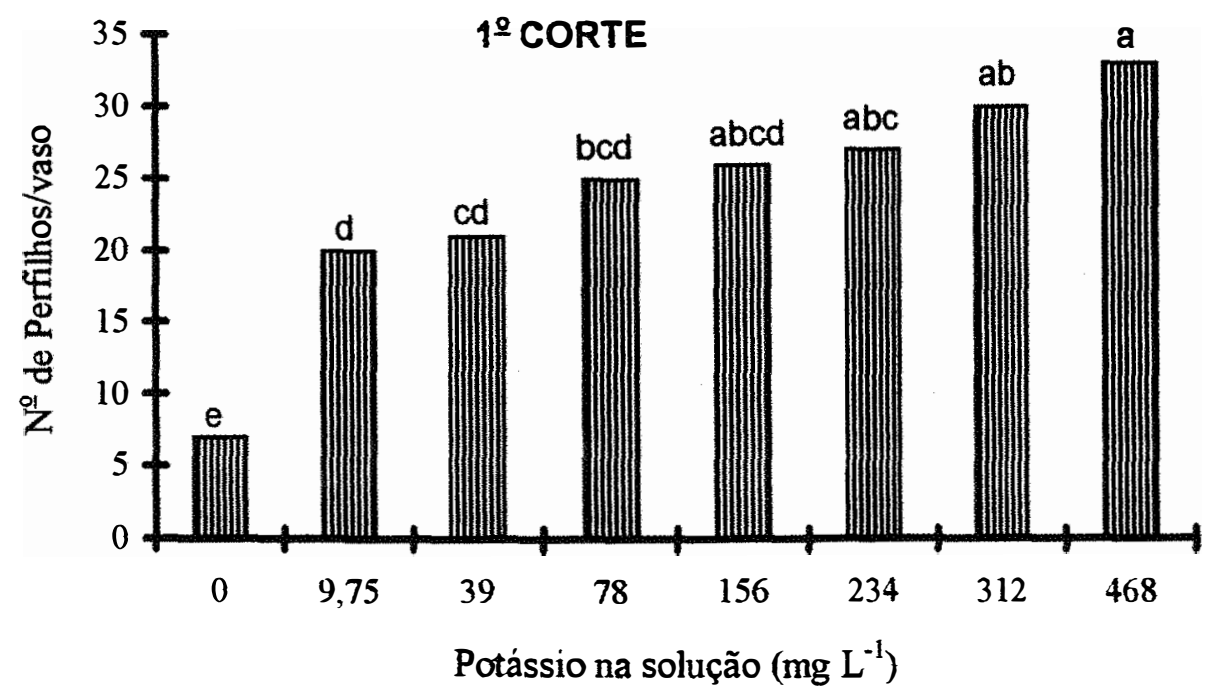

Figura 3 - Número de perfilhos nas cinco plantas de Brachiaria decumbens Stapf. cv. Basilisk, no primeiro crescimento, em função das doses de potássio na solução nutritiva. (Letras diferentes indicam diferença significativa ao nível de $5 \%$ de probabilidade) 
Para o segundo crescimento o emprego do potássio no substrato resultou em um aumento no número de perfilhos nas doses de 312 e $468 \mathrm{mg} \mathrm{K} \mathrm{L}^{-1}$ em relação às demais doses de potássio $\left(0 ; 9,75 ; 39 ; 78 ; 156\right.$ e $\left.234 \mathrm{mg} \mathrm{K} \mathrm{L}^{-1}\right)$ utilizadas (Figura 4).

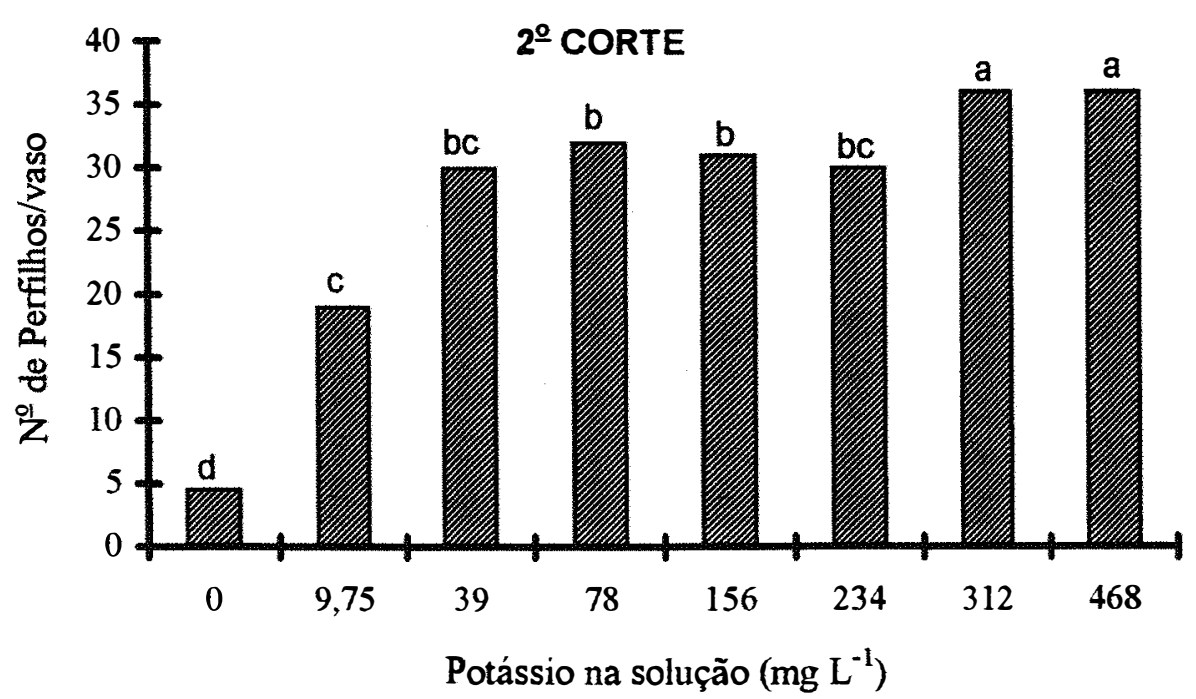

Figura 4 - Número de perfilhos nas cinco plantas de Brachiaria decumbens Stapf. cv. Basilisk, no segundo crescimento, em função das doses de potássio na solução nutritiva. (Letras diferentes indicam diferença significativa ao nível de $5 \%$ de probabilidade)

\subsubsection{Concentração de potássio nos tecidos vegetais}

\subsubsection{Folhas não-expandidas}

A concentração de potássio nas folhas não-expandidas da espécie Brachiaria decumbens Stapf. cv. Basilisk sofreu incrementos significativos 
$(\mathrm{P}<0,01)$, em ambos os cortes realizados, em função das doses de potássio utilizadas.

No primeiro corte, a concentração de potássio variou segundo uma equação de segundo grau, em função das doses de potássio utilizadas na solução nutritiva (Figura 5). O ponto de máxima concentração de potássio nessa parte da gramínea ocorreu com fornecimento de $346 \mathrm{mg} \mathrm{K} \mathrm{L}^{-1}$. Os teores de potássio na matéria seca da Brachiaria decumbens Stapf. cv. Basilisk estiveram entre 11,50 e $35,45 \mathrm{~g} \mathrm{~kg}^{-1}$ nas folhas não-expandidas, em função das doses de potássio.

No material vegetal proveniente do segundo corte, a concentração de potássio variou de forma quadrática com as doses de potássio utilizadas na solução nutritiva, quando se consideraram as folhas não-expandidas (Figura 6). O teor de potássio nas folhas não-expandidas variou entre 14,42 e $33,06 \mathrm{~g} \mathrm{~kg}^{-1}$ e a máxima concentração de potássio ocorreu com a aplicação de $315 \mathrm{mg} \mathrm{K} \mathrm{L}^{-1}$. A concentração de potássio nessa parte da planta para o segundo corte foi semelhante àquela no primeiro corte, em todas as doses de potássio. 


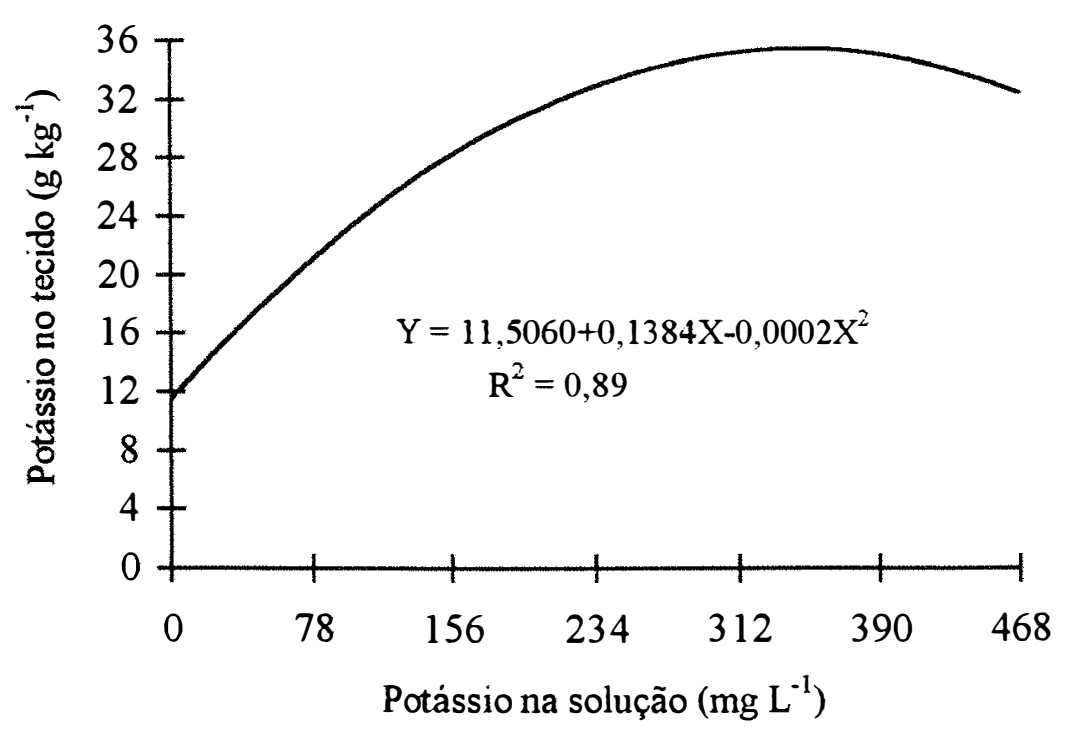

Figura 5 - Concentração de potássio nas folhas não-expandidas, no primeiro corte, da Brachiaria decumbens Stapf. cv. Basilisk, em função das doses de potássio na solução nutritiva.

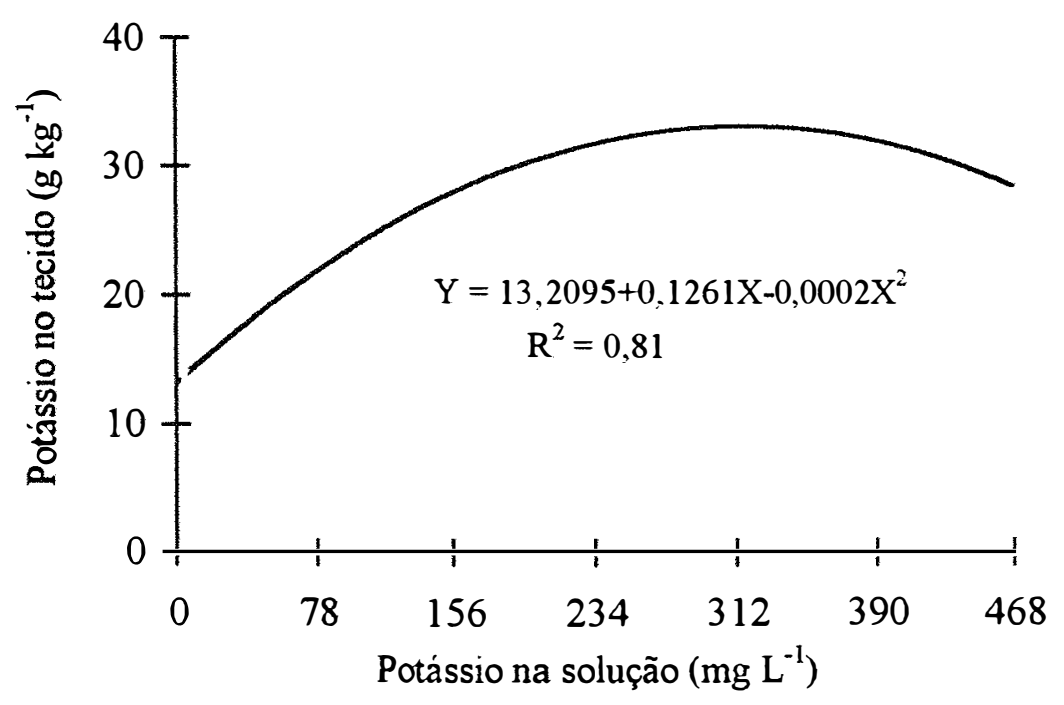

Figura 6 - Concentração de potássio nas folhas não-expandidas, no segundo corte, da Brachiaria decumbens Stapf. cv. Basilisk, em função das doses de potássio na solução nutritiva. 


\subsubsection{Lâminas de folhas novas}

Os resultados referentes à concentração de potássio nas lâminas de folhas novas demonstraram efeito significativo $(\mathrm{P}<0,01)$ para as doses de potássio presentes na solução nutritiva, ajustando-se, tanto no primeiro como no segundo crescimento das plantas, a modelos quadráticos de regressão (Figuras 7 e 8).

Houve um aumento na concentração de potássio nas lâminas de folhas novas desse capim, em função do aumento do potássio na solução, que variou entre 5,61 e 29,63 $\mathrm{g} \mathrm{kg}^{-1}$ no primeiro corte (Figura 7). Na presença de $414 \mathrm{mg} \mathrm{K}$ $\mathrm{L}^{-1}$ obteve-se a máxima concentração de potássio no tecido. No trabalho de Faquin et al. (1995) o ponto de máxima concentração de potássio nas folhas de Brachiaria decumbens Stapf. foi obtido além da máxima dose de potássio utilizada (400 $\mathrm{mg} \mathrm{kg}^{-1}$ de solo), no primeiro corte. Na dose de $400 \mathrm{mg} \mathrm{kg}^{-1}$ de solo a concentração de potássio determinada foi de $19,08 \mathrm{~g} \mathrm{~kg}^{-1}$, a qual ficou abaixo da encontrada neste experimento.

No segundo crescimento o ponto de máxima concentração de potássio nessa parte da gramínea ocorreu com $430 \mathrm{mg} \mathrm{K} \mathrm{L}^{-1}$, correspondendo a uma concentração de $30,41 \mathrm{~g} \mathrm{~K} \mathrm{~kg}^{-1}$ de matéria seca. 


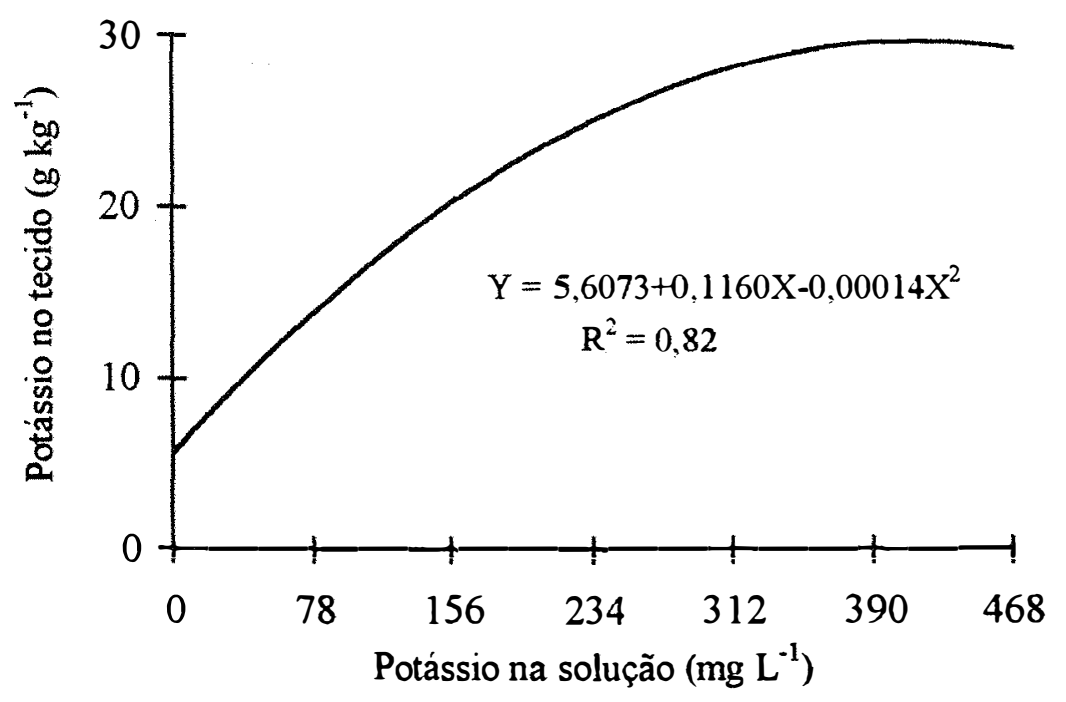

Figura 7 - Concentração de potássio nas lâminas de folhas novas, no primeiro corte, da Brachiaria decumbens Stapf. cv. Basilisk, em função das doses de potássio na solução nutritiva.

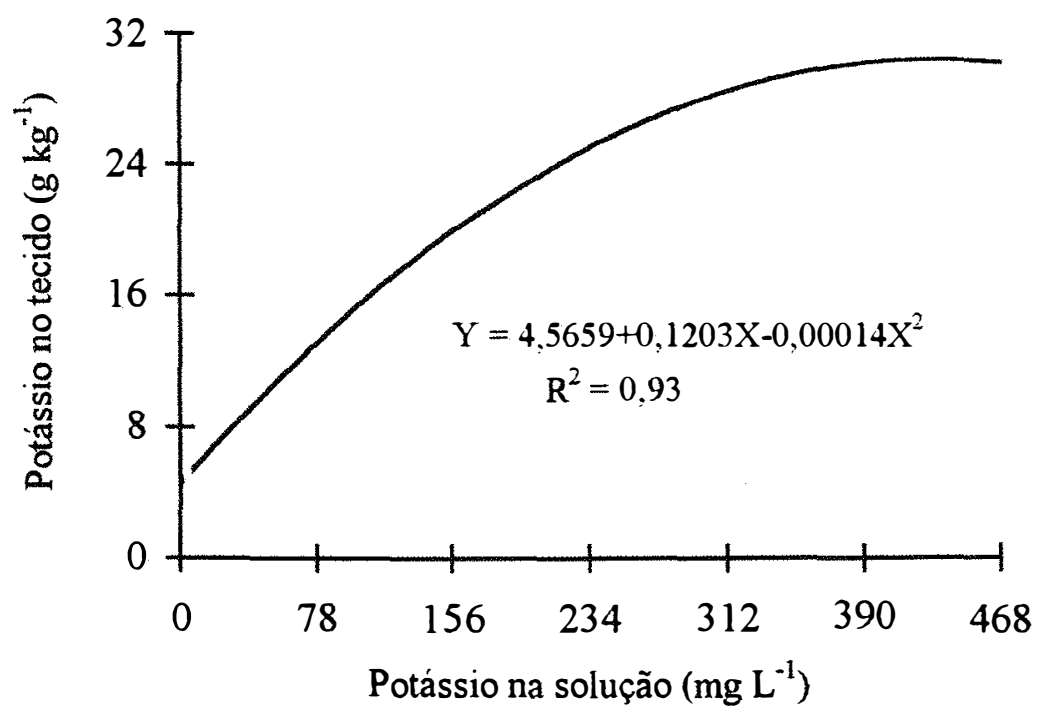

Figura 8 - Concentração de potássio nas lâminas de folhas novas, no segundo corte, da Brachiaria decumbens Stapf. cv. Basilisk, em função das doses de potássio na solução nutritiva. 


\subsubsection{Lâminas de folhas velhas}

A análise de variância dos resultados de concentração de potássio nas lâminas de folhas velhas da Brachiaria decumbens Stapf. revelou aumentos significativos $(\mathrm{P}<0,01)$, em ambos os cortes, em função do suprimento de potássio no substrato.

O teor de potássio nas lâminas de folhas velhas da forrageira coletadas no primeiro corte variou segundo um modelo quadrático com as doses de potássio estudadas. Para qualquer dose de potássio utilizada de 0 a $456 \mathrm{mg} \mathrm{K} \mathrm{L}^{-1}$ a concentração de potássio nas lâminas de folhas velhas foi aumentada quando houve variação no potássio na solução (Figura 9). Em $456 \mathrm{mg} \mathrm{K} \mathrm{L}^{-1}$ ocorreu a máxima concentração de potássio nesse tecido da forrageira. Tal concentração foi de $32,46 \mathrm{~g} \mathrm{~kg}^{-1}$.

Por sua vez, efeitos significativos $(\mathrm{P}<0,01)$ nos teores de potássio nessa parte da planta no segundo período de crescimento, também foram verificados, em função das doses de potássio na solução nutritiva. O ponto de máxima concentração de potássio nessa parte da gramínea ocorreria além do limite de potássio utilizado na solução nutritiva (Figura 10). Nas lâminas de folhas velhas da Brachiaria decumbens, a concentração de potássio nesse corte variou entre 1,94 e $32,46 \mathrm{~g} \mathrm{~kg}^{-1}$. 


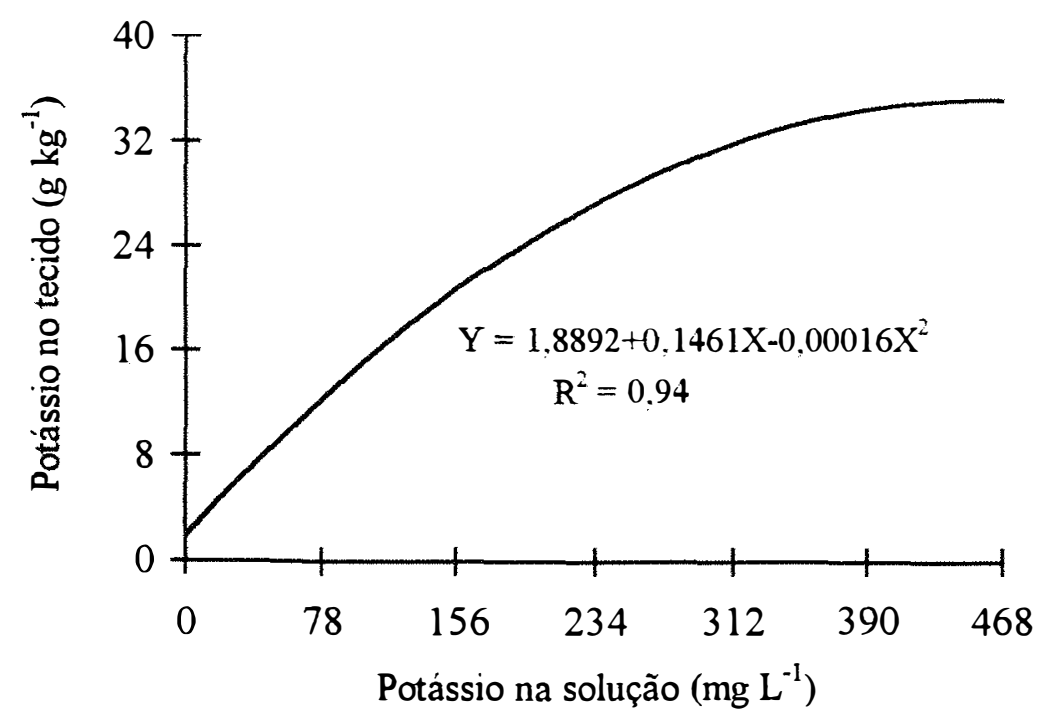

Figura 9 - Concentração de potássio nas lâminas de folhas velhas, no primeiro corte, da Brachiaria decumbens Stapf cv. Basilisk, em função das doses de potássio na solução nutritiva.

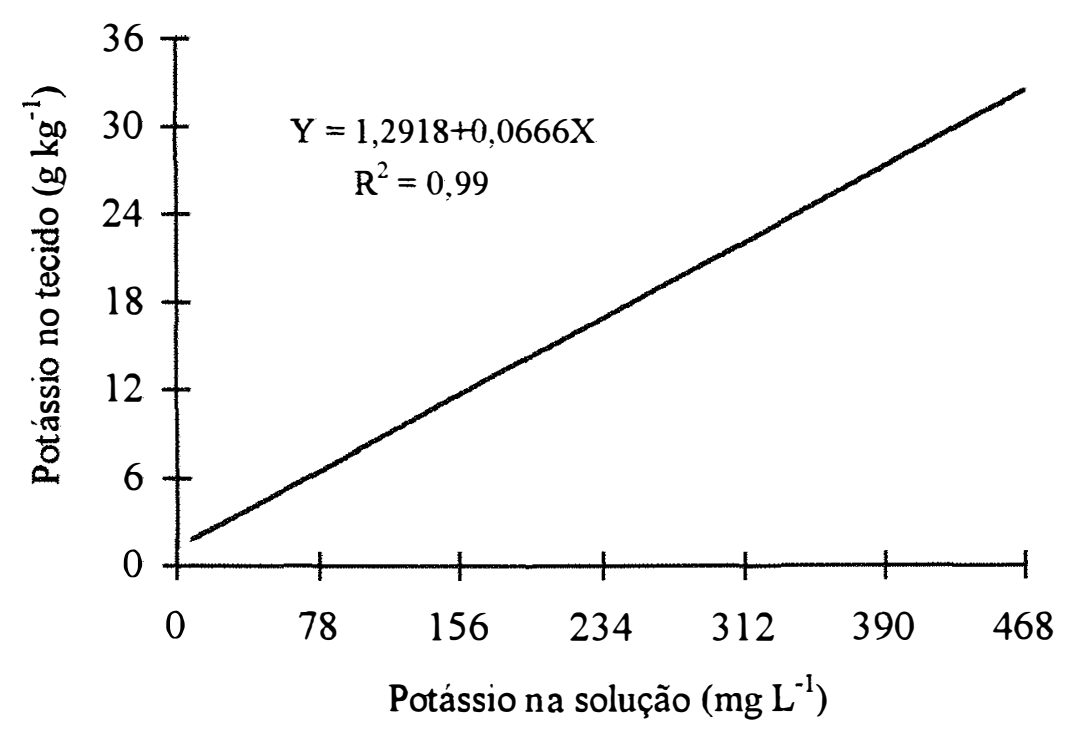

Figura 10 - Concentração de potássio nas lâminas de folhas velhas, no segundo corte, da Brachiaria decumbens Stapf cv. Basilisk, em função das doses de potássio na solução nutritiva. 


\subsubsection{Colmos mais bainhas}

Nos colmos mais bainhas da forrageira a concentração de potássio teve variação significativa $(\mathrm{P}<0,01)$, para ambos os cortes realizados, com o incremento da dose de potássio no substrato.

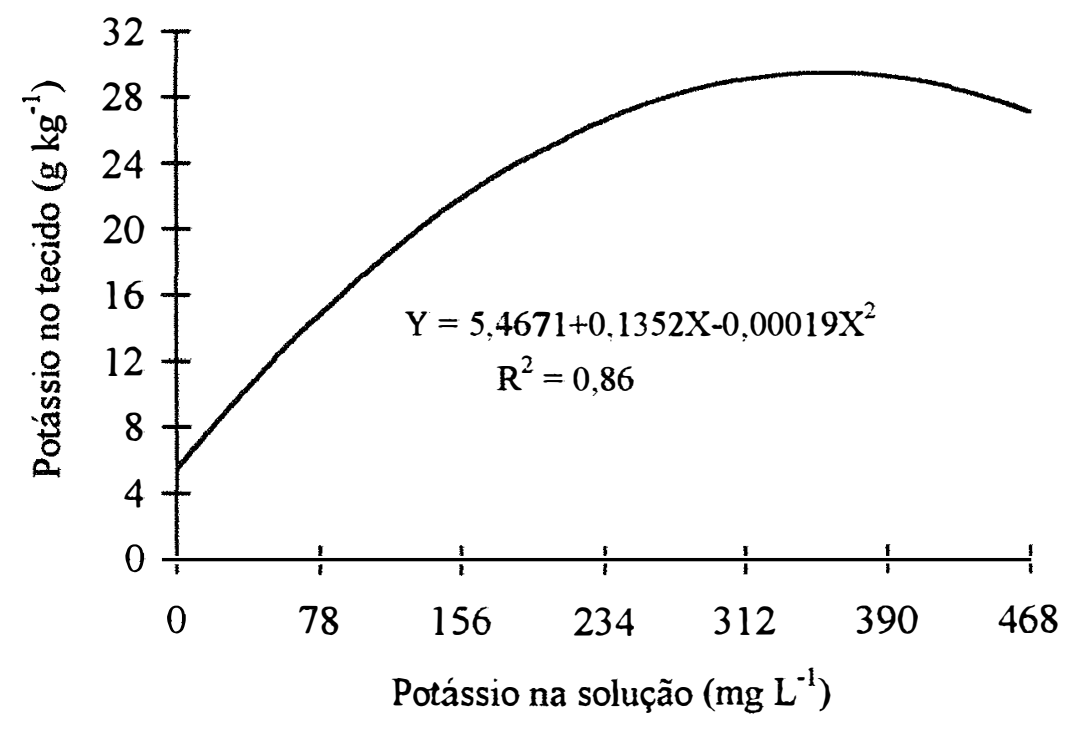

Figura 11 - Concentração de potássio nos colmos mais bainhas, no primeiro corte, da Brachiaria decumbens Stapf. cv. Basilisk, em função das doses de potássio na solução nutritiva.

Tanto no primeiro como no segundo corte (Figuras 11 e 12), o teor de potássio variou segundo uma equação de segundo grau, em função das doses de potássio utilizadas na solução nutritiva. Os pontos de máxima concentração de potássio nessa parte da gramínea ocorreram em 356 e $377 \mathrm{mg} \mathrm{K} \mathrm{L}^{-1}$, no primeiro e segundo corte, respectivamente. Quando a dose de potássio foi de $0 \mathrm{mg} \mathrm{K} \mathrm{L}^{-1}$ a 
concentração do nutriente foi de 5,47 e 1,52 $\mathrm{g} \mathrm{kg}^{-1}$ para primeiro e segundo corte, respectivamente. Já a máxima concentração fícou em $29,52 \mathrm{~g} \mathrm{~kg}^{-1}$ no primeiro corte e $28,45 \mathrm{~g} \mathrm{~kg}^{-1}$ no segundo corte.

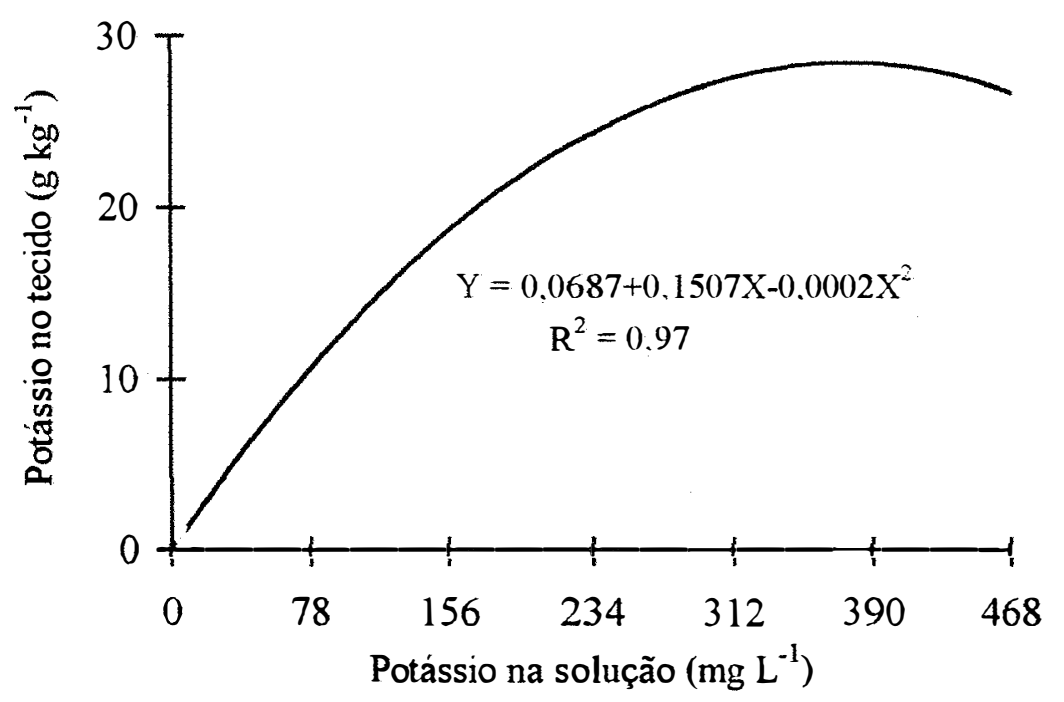

Figura 12 - Concentração de potássio nos colmos mais bainhas, no segundo corte, da Brachiaria decumbens Stapf. cv. Basilisk, em função das doses de potássio na solução nutritiva.

\subsubsection{Raízes}

A concentração de potássio nas raízes da Brachiaria decumbens Stapf. cv. Basilisk sofreu incrementos significativos $(\mathrm{P}<0,01)$ com a elevação das doses desse nutriente na solução.

A concentração de potássio variou segundo uma equação de primeiro grau em função das doses de potássio utilizadas na solução nutritiva (Figura 13). 
Nas raizes da Brachiaria decumbens cv. Basilisk a concentração de potássio variou, nos limites desse experimento entre 1,43 e $30,40 \mathrm{~g} \mathrm{~kg}^{-1}$.

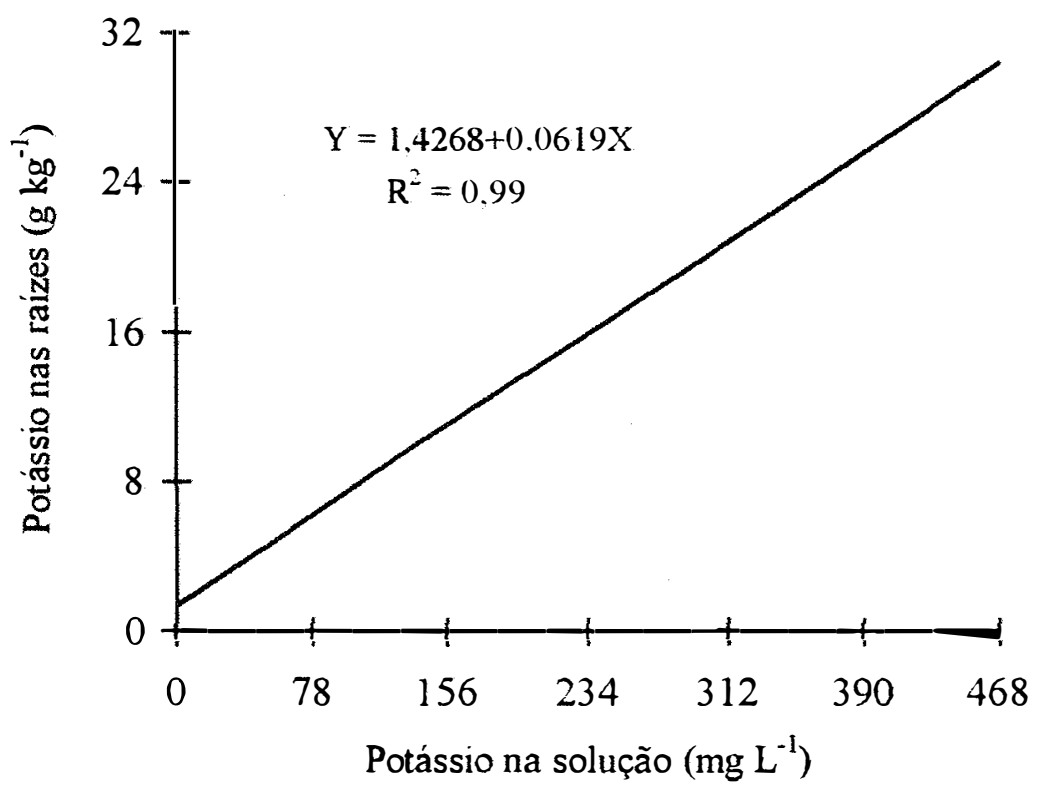

Figura 13 - Concentração de potássio nas raízes da Brachiaria decumbens Stapf cv. Basilisk, em função das doses de potássio na solução nutritiva.

\subsubsection{Sintomas visuais}

Quinze dias após o transplante das mudas para os vasos tornaram-se evidentes os primeiros sintomas de deficiência de potássio nas duas folhas após a folha não-expandida da Brachiaria decumbens Stapf. cv. Basilisk desenvolvida na dose $0 \mathrm{mg} \mathrm{K} \mathrm{L} \mathrm{L}^{-1}$. Esses sintomas se manifestaram por uma clorose na borda das folhas, que se acentuaram em direção à nervura principal, em forma de um "V" invertido. 


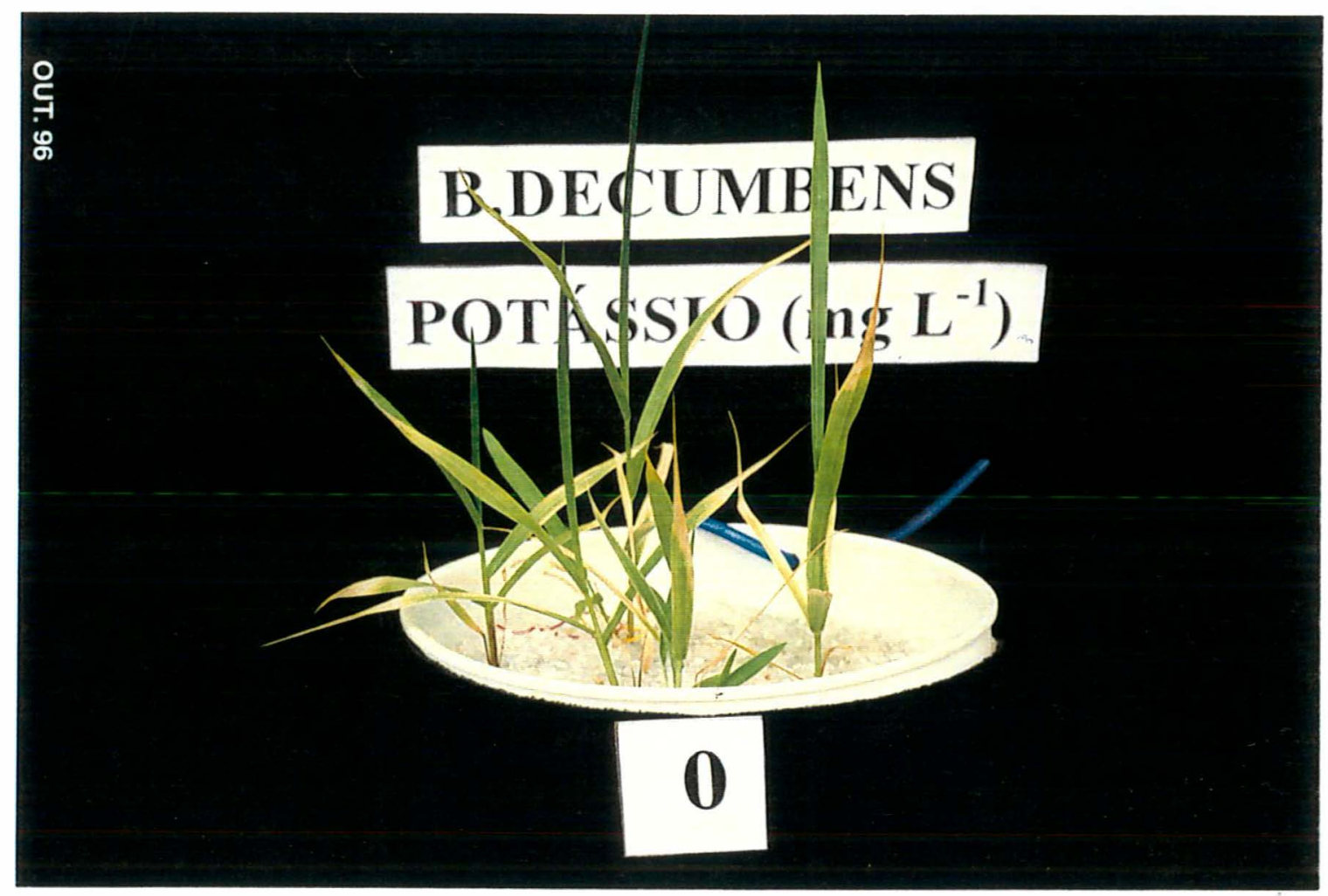

Figura 14 - Sintoma de deficiência de potássio em Brachiaria decumbens Stapf. cv. Basilisk, no primeiro crescimento, com tratamento $0 \mathrm{mg} \mathrm{K} \mathrm{L}^{-1}$.

Aos trinta e oito dias após o transplante da gramínea, na época do primeiro corte, as plantas crescidas na dose $0 \mathrm{mg} \mathrm{K} \mathrm{L} \mathrm{K}^{-1}$, apresentaram uma intensa clorose nas folhas velhas (Figura 14), o mesmo ocorrendo com menos intensidade nas folhas velhas das plantas submetidas à dose de $9,75 \mathrm{mg} \mathrm{K} \mathrm{L}^{-1}$.

Após o primeiro corte, as plantas crescidas nas doses de $0,9,75$ e $39 \mathrm{mg}$ $\mathrm{K} \mathrm{L}^{-1}$ apresentavam sintomas de deficiência de potássio nas lâminas de folhas 
velhas. Sintomas semelhantes a esses foram relatados por Carvalho et al. (1991) em Brachiaria decumbens, Monteiro et al.(1995) em Brachiaria brizantha cv. Marandu e Vicente-Chandler et al. (1962) e Monteiro et al. (1980) em Panicum maximum.

\subsubsection{Distribuição do potássio na parte aérea}

A quantidade de potássio em cada componente da parte aérea foi incrementada pelo maior suprimento de potássio na solução nutritiva. Todavia, em termos de participação porcentual, a quantidade de potássio nos colmos mais bainhas representaram em torno de 38 a $50 \%$ da quantidade de potássio presente na parte aérea, no primeiro corte e de 37 a $65 \%$, por ocasião do segundo corte da forrageira.

Por outro lado, em ambos os cortes a distribuição do potássio nas folhas não-expandidas decresceu de $17 \%$ para $10 \%$ no primeiro corte e $25 \%$ para $6 \%$ no segundo corte, em função das doses de potássio utilizadas, enquanto que nas lâminas de folhas novas e lâminas de folhas velhas as diferenças no porcentual de potássio presente nessas partes foram pequenas em relação às demais partes (Tabela 2), em ambos os cortes. 
Tabela 2 - Distribuição porcentual da quantidade de potássio nas partes da parte aérea da Brachiaria decumbens $\mathrm{cv}$. Basilisk submetida a doses de potássio, em cada um dos cortes.

\begin{tabular}{|c|c|c|c|c|c|c|c|c|}
\hline \multirow{2}{*}{$\mathrm{mg} \mathrm{K} \mathrm{L}^{-1}$} & \multicolumn{4}{|c|}{ Primeiro corte* } & \multicolumn{4}{c|}{ Segundo corte* } \\
\cline { 2 - 9 } & FN & LN & LV & CB & FN & LN & LV & CB \\
\hline 0 & 17,0 & 34,8 & 20,4 & 27,8 & $* *$ & $* *$ & $* *$ & $* *$ \\
\hline 9,75 & 16,9 & 30,7 & 13,9 & 38,5 & 15,7 & 29,6 & 17,3 & 37,4 \\
\hline 39 & 16,8 & 32,9 & 6,5 & 43,8 & 25,0 & 29,4 & 5,4 & 40,2 \\
\hline 78 & 11,1 & 28,3 & 11,6 & 49,0 & 15,2 & 27,1 & 7,5 & 50,2 \\
\hline 156 & 8,3 & 21,2 & 13,8 & 56,7 & 9,7 & 24,6 & 8,2 & 57,5 \\
\hline 234 & 9,5 & 26,7 & 19,6 & 44,2 & 7,0 & 19,4 & 9,0 & 64,6 \\
\hline 312 & 11,3 & 24,7 & 14,4 & 49,6 & 6,1 & 18,2 & 10,6 & 65,0 \\
\hline 468 & 10,0 & 27,0 & 16,3 & 46,7 & 6,1 & 19,5 & 12,3 & 62,0 \\
\hline
\end{tabular}

*FN = folhas não-expandidas; $\mathrm{LN}$ = lâminas de folhas novas; $\mathrm{LV}=$ lâminas de folhas velhas; $\mathrm{CB}=$ Colmos + Bainhas.

** Não foi determinado o teor de potássio, por insuficiência de material.

\subsubsection{Níveis críticos de potássio}

O estudo das correlações entre os teores de potássio nas quatro partes amostradas e a produção de matéria seca da parte aérea das plantas revelou que a melhor correlação ocorreu para as concentrações de potássio em lâminas de folhas novas e a produção de matéria seca da parte aérea, em ambos os cortes (coeficientes de correlação igual a $0,89^{* * *}$ e $0,88^{* * *}$, no primeiro e segundo cortes, respectivamente).

Adotou-se o conceito de nível crítico estabelecido por Ulrich \& Hill (1973), o qual é representado pela concentração do nutriente que corresponde a $90 \%$ da produção ótima da cultura. 
A relação entre as concentrações de potássio e a produção de matéria seca da parte aérea foi traduzida, em ambos os cortes, por modelo quadrático para as lâminas de folhas novas. Para o material do primeiro e do segundo corte, o nível crítico de potássio nas lâminas de folhas novas (para $90 \%$ da máxima produção) seria de 23 e de $20 \mathrm{~g} \mathrm{~kg}^{-1}$ matéria seca (Figuras 15 e 16). Esses valores são mais altos que os encontrados no trabalho de Faquin et al. (1995) no qual o nível crítico de potássio na parte aérea do primeiro corte (correspondente a $90 \%$ da produção máxima) foi de $13,5 \mathrm{~g} \mathrm{~kg}^{-1}$ para a braquiária decumbens e Carvalho et al. (1989) que apontaram níveis críticos de potássio na matéria seca da parte aérea da braquiária na faixa de 10,0 a $15,0 \mathrm{~g} \mathrm{~kg}^{-1}$. Rao et al. (1996) apresentaram nível crítico de potássio na matéria seca da parte aérea da braquiária decumbens em torno de $8,3 \mathrm{~g} \mathrm{~kg}^{-1}$. $\mathrm{O}$ fato dos valores serem mais altos no presente experimento pode estar relacionado com a translocação do potássio das partes velhas para as mais novas.

Pela facilidade de execução da amostragem, a utilização de lâminas das duas folhas mais novas completamente expandidas também se mostra adequada para fins de diagnose nutricional de potássio em Brachiaria decumbens Stapf. cv. Basilisk. 


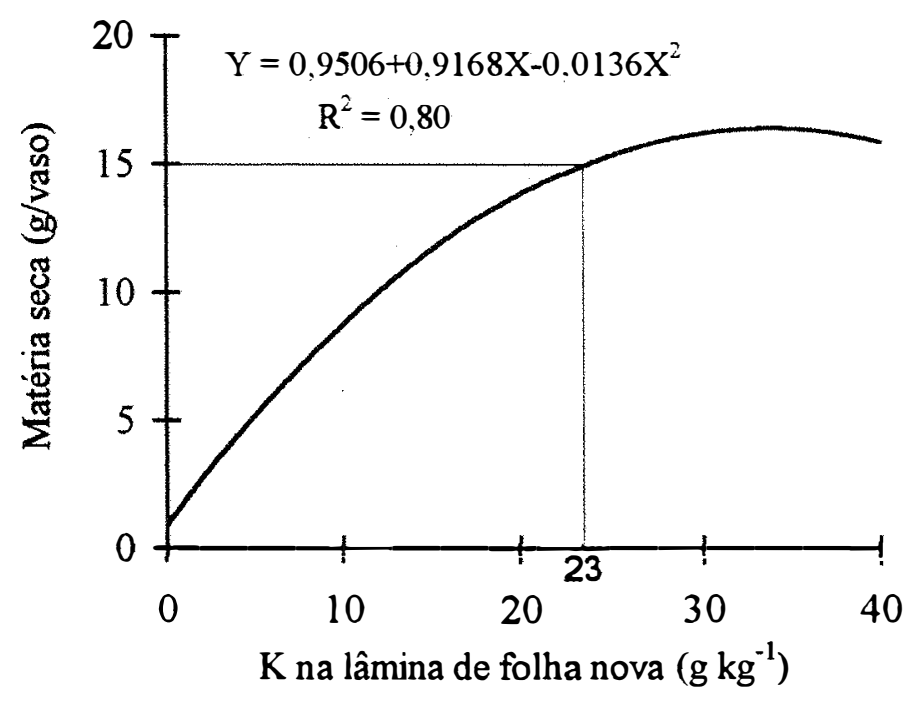

Figura 15 - Relação entre a produção de matéria seca da parte aérea e a concentração de potássio nas lâminas de folhas novas de Brachiaria decumbens cv. Basilisk, no primeiro corte.

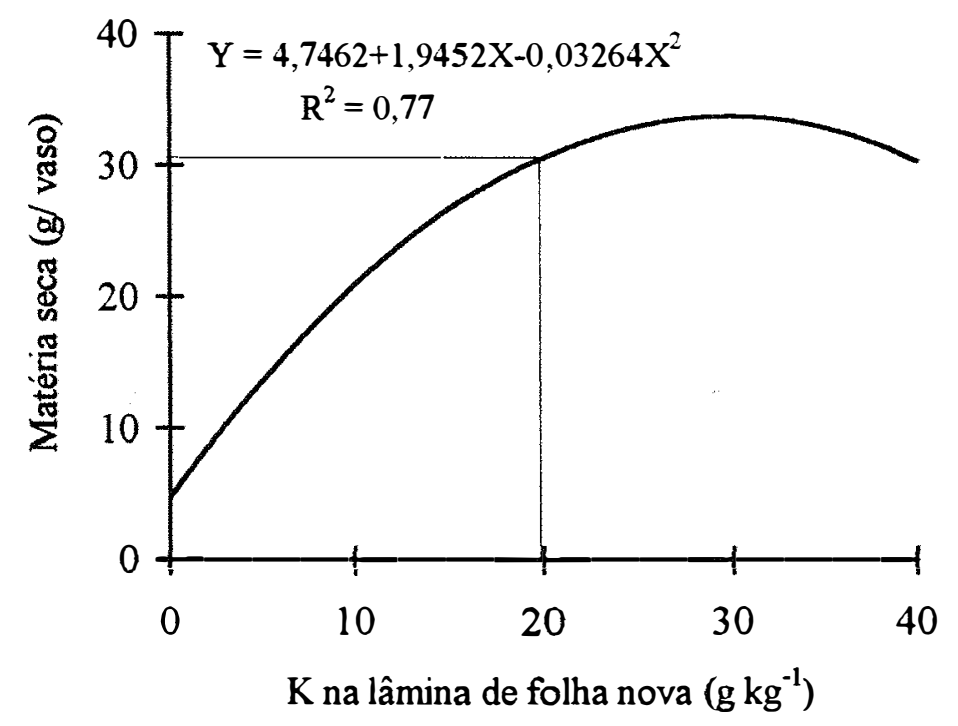

Figura 16 - Relação entre a produção de matéria seca da parte aérea e a concentração de potássio nas lâminas de folhas novas de Brachiaria decumbens cv. Basilisk, no segundo corte. 


\subsection{Experimento com Brachiaria brizantha (Hochst ex A.Rich.) Stapf.}

\section{cv. Marandu}

\subsubsection{Produção de matéria seca da parte aérea e das raízes}

A produção de matéria seca da parte aérea da Brachiaria brizantha (Hochst ex A.Rich.) Stapf. cv. Marandu teve incrementos significativos $(\mathrm{P}<0,01)$ com a adição de potássio na solução nutritiva, em ambos os cortes, ajustando-se a um modelo quadrático tanto no primeiro como no segundo corte (Figura 17).

No primeiro corte observou-se que a produção de matéria seca da parte aérea atingiu seu ponto de máximo com a dose de $365 \mathrm{mg} \mathrm{K} \mathrm{L}^{-1}$, conforme apresentado na figura 17. Para o segundo corte a produção máxima de matéria seca da parte aérea foi obtida com a utilização de $399 \mathrm{mg} \mathrm{K} \mathrm{L}^{-1}$, como mostrado na figura 17. 


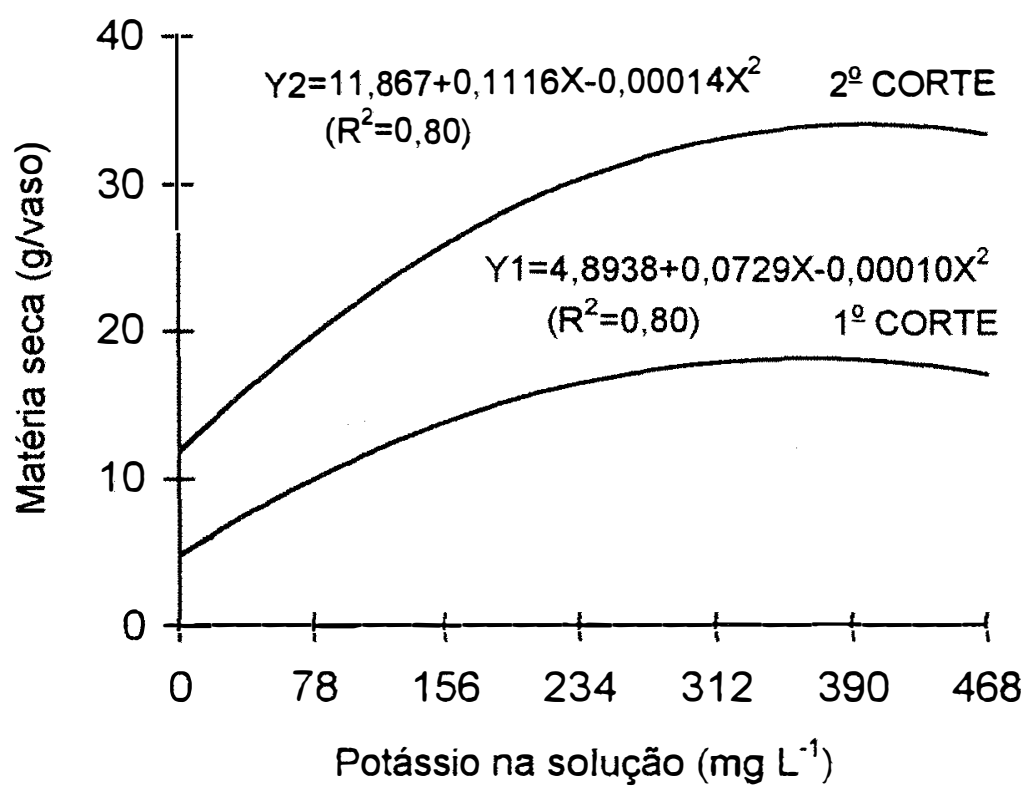

Figura 17 - Produção de matéria seca da parte aérea da Brachiaria brizantha (Hochst ex A.Rich.) Stapf. cv. Marandu, no primeiro e segundo corte, em função das doses de potássio na solução nutritiva.

A produção de matéria seca da parte aérea dessa forrageira sofreu incremento em função das doses fornecidas de potássio, o que concorda com Faquin et al. (1995) que relataram aumento significativo na produção de matéria seca da parte aérea da Brachiaria decumbens Stapf. e Panicum maximum Jacq. nos dois cortes, cujas equações de regressão também mostraram uma relação quadrática para o potássio. Mesa et al. (1989) verificaram aumento significativo na produção quando o potássio foi aplicado em dose de até $25 \mathrm{mg} \mathrm{K} \mathrm{kg}^{-1}$ de solo para Bermuda 68, Likoni e Rhodes callide, enquanto que para o Buffel formidable o aumento significativo foi até $75 \mathrm{mg} \mathrm{K} \mathrm{kg}^{-1}$ de solo. Silva et al. (1995) também puderam verificar respostas positivas na produção de matéria seca da parte aérea 
do capim-Tanzânia-1 cultivado em doses de potássio enquanto Vicente-Chandler et al. (1962) cultivaram capim-colonião e relataram aumentos na produção de matéria seca em função do suprimento de potássio. Já Monteiro et al. (1995) relataram que a omissão de potássio na solução nutritiva não resultou em redução significativa na produção de matéria seca, quando comparada ao tratamento completo (234 mg K L ${ }^{-1}$ ) na Brachiaria brizantha (Hochst ex A.Rich.) Stapf. cv. Marandu.

$\mathrm{Na}$ dose $0 \mathrm{mg} \mathrm{K \textrm {L } ^ { - 1 }}$ as produções de matéria seca da parte aérea da Brachiaria brizantha (Hochst ex A.Rich.) Stapf. cv. Marandu representaram cerca de 27,0 e $35,0 \%$ das máximas alcançadas nos dois cortes. Estes valores são semelhantes aos relatados por Ferrari Neto (1991) com Brachiaria decumbens Stapf. e que foram 30 e $41 \%$ inferiores ao tratamento completo.

A produção de matéria seca das raízes variou significativamente $(\mathrm{P}<0,01)$ com as doses de potássio, atingindo seu ponto máximo com o emprego de $268 \mathrm{mg} \mathrm{K} \mathrm{L}^{-1}$ (Figura 18). 


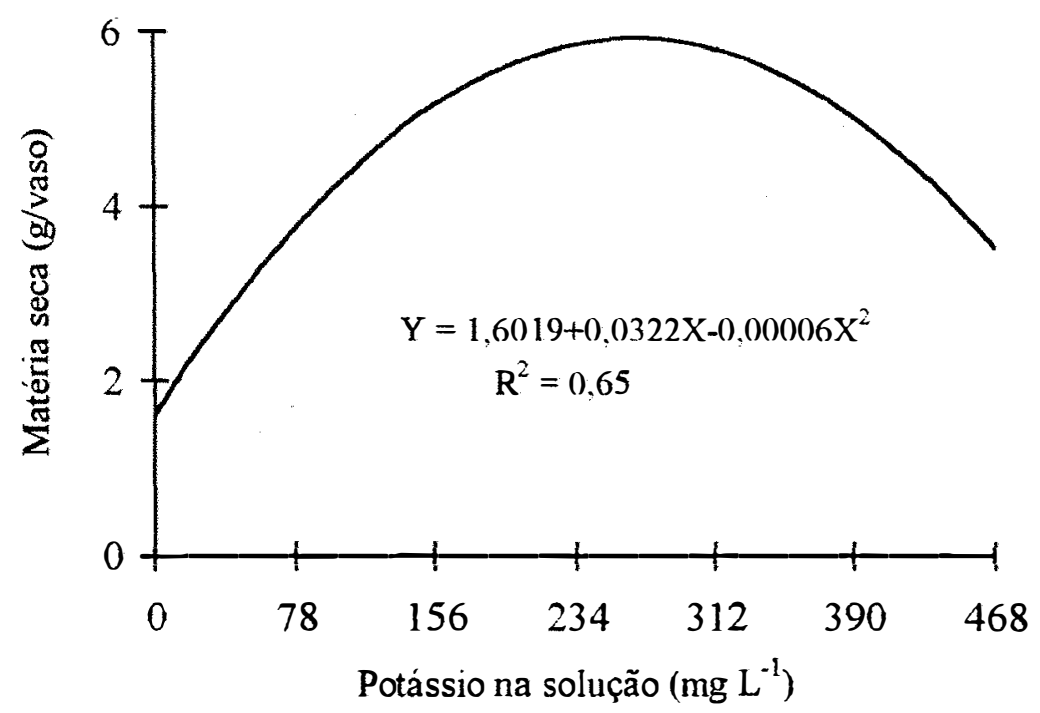

Figura 18 - Produção de matéria seca das raízes da Brachiaria brizantha (Hochst ex A.Rich.) Stapf. cv. Marandu, em função das doses de potássio na solução nutritiva.

\subsubsection{Número de perfilhos}

O aumento nas doses de potássio na solução nutritiva promoveu incrementos significativos $(\mathrm{P}<0,05)$ no número de perfilhos da Brachiaria brizantha (Hochst ex A.Rich.) Stapf. cv. Marandu, nos dois períodos de crescimento, como mostram as figuras 19 e 20 . Por outro lado, Monteiro et al. (1995) não encontraram variação significativa no perfilhamento da Brachiaria brizantha (Hochst ex A.Rich.) Stapf. cv. Marandu na comparação da omissão de potássio com o tratamento completo $\left(234 \mathrm{mg} \mathrm{K} \mathrm{L}^{-1}\right)$.

No primeiro período de crescimento o número de perfilhos aumentou da dose de potássio de $0 \mathrm{mg} \mathrm{K} \mathrm{L}{ }^{-1}$ para a dose $9,75 \mathrm{mg} \mathrm{K} \mathrm{L}^{-1}$ não variando 
significativamente de 9,75 a $234 \mathrm{mg} \mathrm{K} \mathrm{L}^{-1}$, mas tendo o valor significativamente mais elevado na dose $468 \mathrm{mg} \mathrm{K} \mathrm{L}^{-1}$ (Figura 19). Já no segundo crescimento o número de perfilhos aumentou da dose de potássio de $9,75 \mathrm{mg} \mathrm{K} \mathrm{L}^{-1}$ para a 39 $\mathrm{mg} \mathrm{K} \mathrm{L}{ }^{-1}$ e não variando entre 39 e $312 \mathrm{mg} \mathrm{L}^{-1}$. Porém, na dose de $468 \mathrm{mg} \mathrm{K} \mathrm{L}^{-1}$ o número de perfilhos foi significativamente mais elevado que aquele verificado nas doses igual ou inferiores a $234 \mathrm{mg} \mathrm{K} \mathrm{L}^{-1}$ de solução (Figura 20).

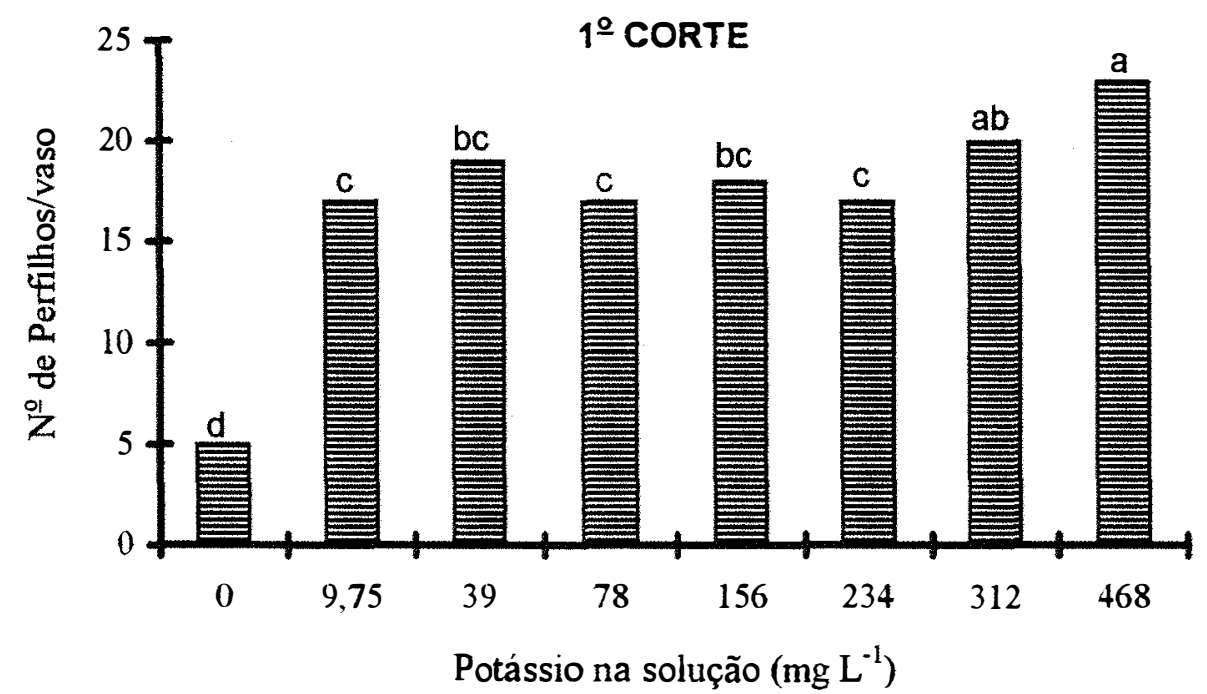

Figura 19 - Número de perfilhos nas cinco plantas de Brachiaria brizantha (Hochst ex A.Rich.) Stapf. cv. Marandu, no primeiro crescimento, em função das doses de potássio na solução nutritiva. (Letras diferentes indicam diferença significativa ao nível de $5 \%$ de probabilidade) 


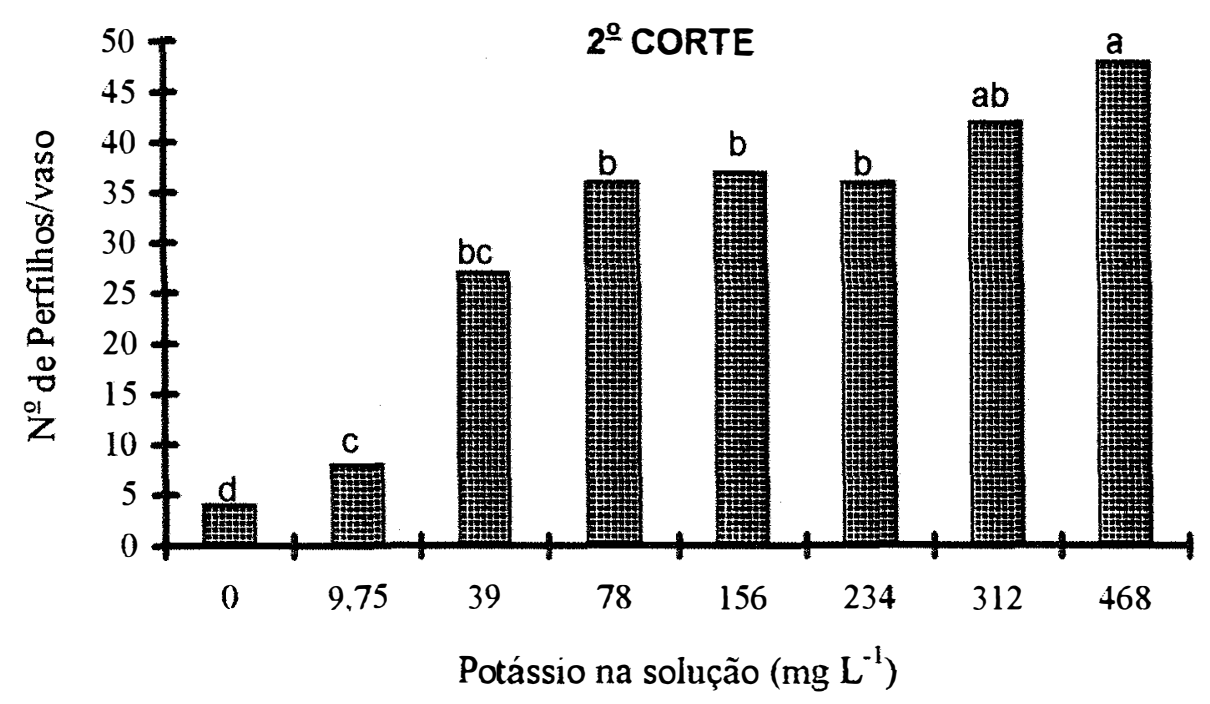

Figura 20 - Número de perfilhos nas cinco plantas de Brachiaria brizantha (Hochst ex A.Rich.) Stapf. cv. Marandu, no segundo crescimento, em função das doses de potássio na solução nutritiva. (Letras diferentes indicam diferença significativa ao nível de $5 \%$ de probabilidade)

\subsubsection{Concentração de potássio nos tecidos vegetais}

\subsubsection{Folhas não-expandidas}

Os resultados referentes às folhas não-expandidas apresentaram efeitos significativos $(\mathrm{P}<0,01)$ para as doses de potássio em solução nutritiva, ajustandose no primeiro e no segundo corte a modelos quadráticos de regressão (Figuras 21 e 22).

A concentração de potássio obtida no material do primeiro corte dessa gramínea, foi aumentada pelas doses de potássio aplicadas na solução nutritiva. A 
variação na concentração de potássio nessa parte da planta dessa espécie foi de 14,60 a $52,92 \mathrm{~g} \mathrm{~kg}^{-1}$.

$\mathrm{Na}$ amostragem à época do segundo corte as concentrações de potássio nas folhas não-expandidas da Brachiaria brizantha (Hochst ex A.Rich.) Stapf. cv. Marandu estiveram na faixa de $12,32 \mathrm{~g} \mathrm{~kg}^{-1}$ quando a dose era de $9,75 \mathrm{mg} \mathrm{K} \mathrm{L}^{-1}$ a $30,44 \mathrm{~g} \mathrm{~kg}^{-1}$ para dose de $399 \mathrm{mg} \mathrm{L}^{-1}$ (esta dose sendo a que propiciou a máxima concentração de potássio nesse tecido do capim).

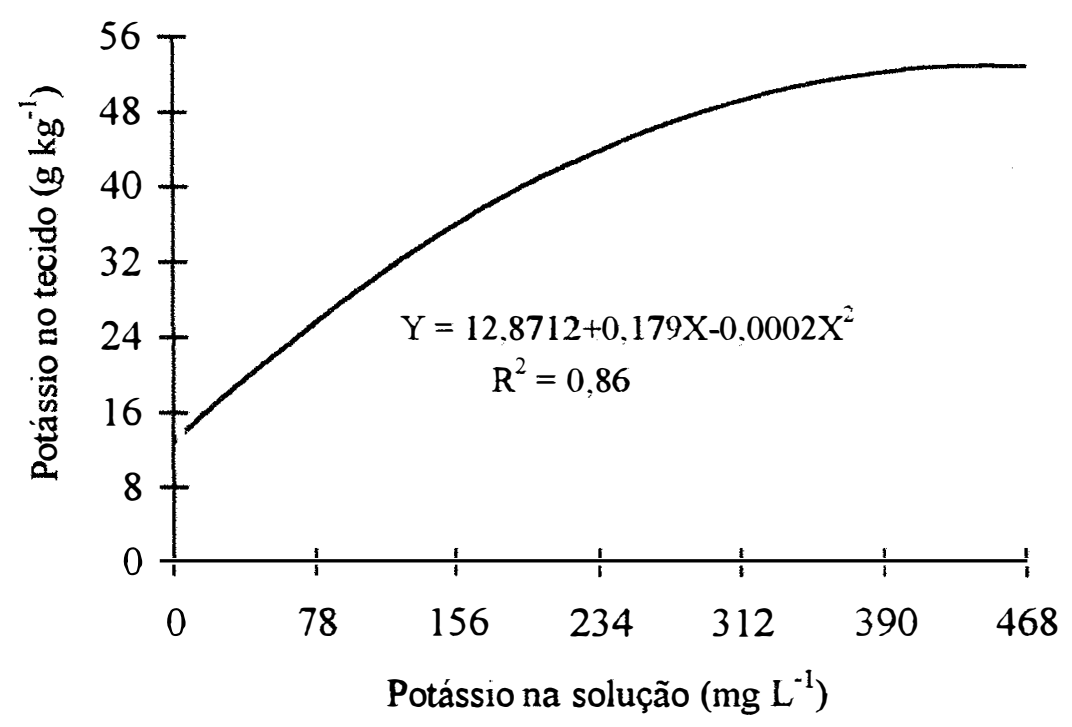

Figura 21 - Concentração de potássio nas folhas não-expandidas, no primeiro corte, a Brachiaria brizantha (Hochst ex A.Rich.) Stapf. cv. Marandu, em função das doses de potássio na solução nutritiva. 


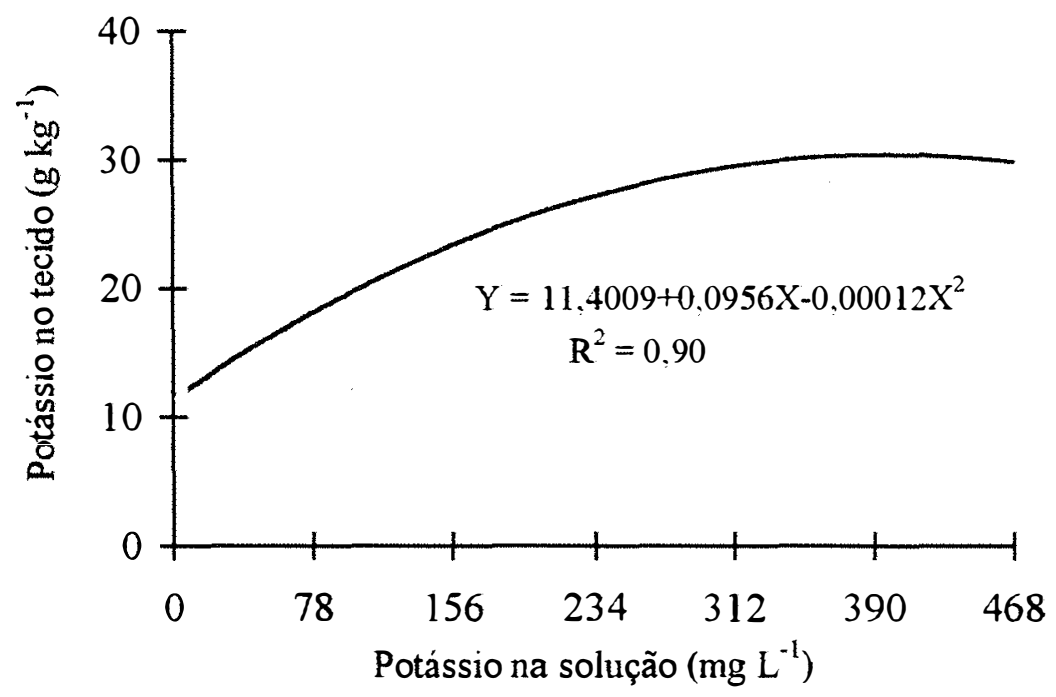

Figura 22 - Concentração de potássio nas folhas não-expandidas, no segundo corte, da Brachiaria brizantha (Hochst ex A.Rich.) Stapf. cv. Marandu, em função das doses de potássio na solução nutritiva.

\subsubsection{Lâminas de folhas novas}

A análise da concentração de potássio nas lâminas de folhas novas da Brachiaria brizantha (Hochst ex A.Rich.) Stapf. cv. Marandu revelou incrementos significativos $(\mathrm{P}<0,01)$, tanto para o primeiro período de crescimento como para o segundo período, em função do suprimento de potássio no substrato.

No material coletado ao final do primeiro crescimento constatou-se que as variações na concentração de potássio nesse tecido vegetal ajustaram-se a uma equação de segundo grau (Figura 23). O ponto de máxima concentração de potássio nessa parte da gramínea ocorreu em presença de $456 \mathrm{mg} \mathrm{K} \mathrm{L}^{-1}$, valor mais elevado que o encontrado por Mattos et al. (1996) em capim-Tanzânia-1, no 
qual foi de $334 \mathrm{mg} \mathrm{K} \mathrm{L}^{-1}$. No presente experimento as lâminas de folhas novas tiveram teores de potássio variando de 6,30 a $66,09 \mathrm{~g} \mathrm{~kg}^{-1}$ entre a dose 9,75 e a de $334 \mathrm{mg} \mathrm{K} \mathrm{L}^{-1}$ de solução.

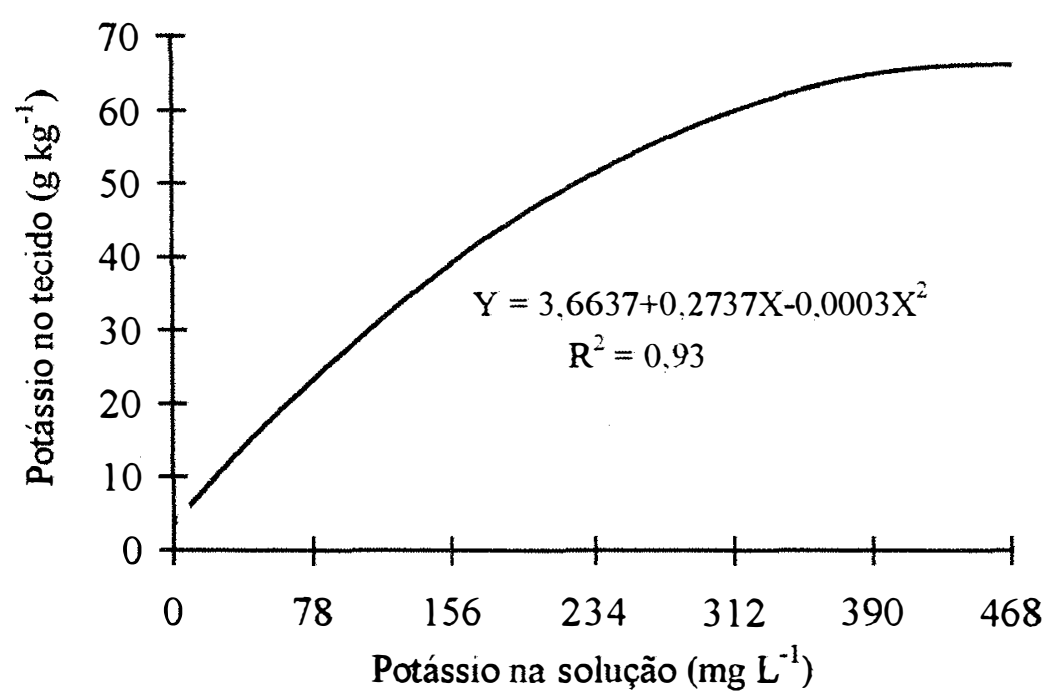

Figura 23 - Concentração de potássio nas lâminas de folhas novas, no primeiro corte, da Brachiaria brizantha (Hochst ex A.Rich.) Stapf. cv. Marandu, em função das doses de potássio na solução nutritiva.

Destaca-se que no segundo período de crescimento a concentração de potássio variou segundo uma equação de primeiro grau em função das doses de potássio na solução nutritiva (Figura 24). Por outro lado, Mattos et al. (1996) obtiveram uma equação de segundo grau para a concentração de potássio nas lâminas de folhas novas do capim-Tanzània-1, em função das doses de potássio, utilizadas, tendo seu ponto de máxima concentração em torno de $365 \mathrm{mg} \mathrm{K} \mathrm{L}^{-1}$. Nas lâminas de folhas novas da Brachiaria brizantha (Hochst ex A.Rich.) Stapf. 
cv. Marandu, a concentração de potássio nesse corte variou entre 7,48 e 31,03 g $\mathrm{kg}^{-1}$, respectivamente, para a menor dose aplicada e a dose mais elevada de potássio do experimento.

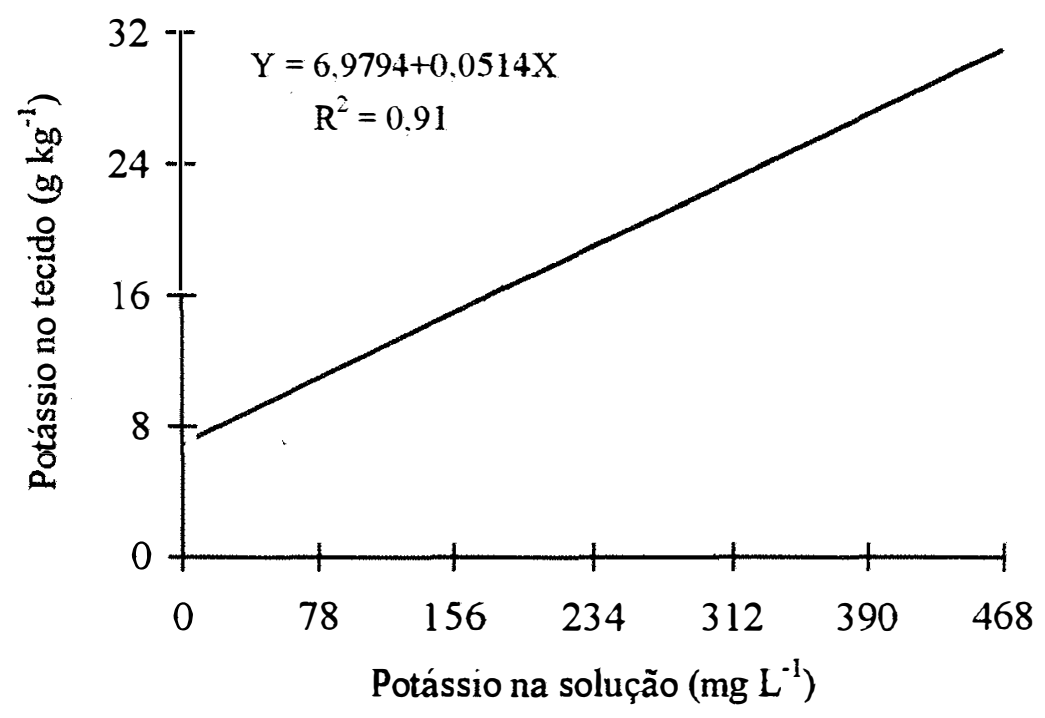

Figura 24 - Concentração de potássio nas lâminas de folhas novas, no segundo corte, da Brachiaria brizantha (Hochst ex A.Rich.) Stapf. cv. Marandu, em função das doses de potássio na solução nutritiva.

\subsubsection{Lâminas de folhas velhas}

Analisando a variação na concentração de potássio nas lâminas de folhas velhas da espécie Brachiaria brizantha cv. Marandu, pode-se notar aumentos significativos $(\mathrm{P}<0,01)$ pelo suprimento de potássio no meio de crescimento, para ambos os cortes (Figuras 25 e 26).

Em termos da concentração de potássio nas lâminas de folhas velhas da forrageira, no primeiro crescimento a concentração de potássio variou segundo 
uma equação de segundo grau em função das doses de potássio utilizadas na solução nutritiva. O mesmo ocorreu para o segundo crescimento.

Mattos et al. (1996), estudando o capim-Tanzânia-1 com doses de potássio, obtiveram ajustes lineares para ambos os cortes, nas lâminas de folhas velhas. No presente experimento os pontos de máxima concentração de potássio dessa braquiária ocorreram em presença de $273 \mathrm{mg} \mathrm{K} \mathrm{L^{-1 }}$ no primeiro crescimento, enquanto no segundo crescimento a máxima concentração ocorreria além da maior dose estudada (664 $\left.\mathrm{mg} \mathrm{K} \mathrm{L}^{-1}\right)$. O teor de potássio nas lâminas de folhas velhas variou de 0,67 a $56,24 \mathrm{~g} \mathrm{~kg}^{-1}$ para o primeiro corte e de 0,94 a 32,09 $\mathrm{g} \mathrm{kg}^{-1}$ para o segundo corte.

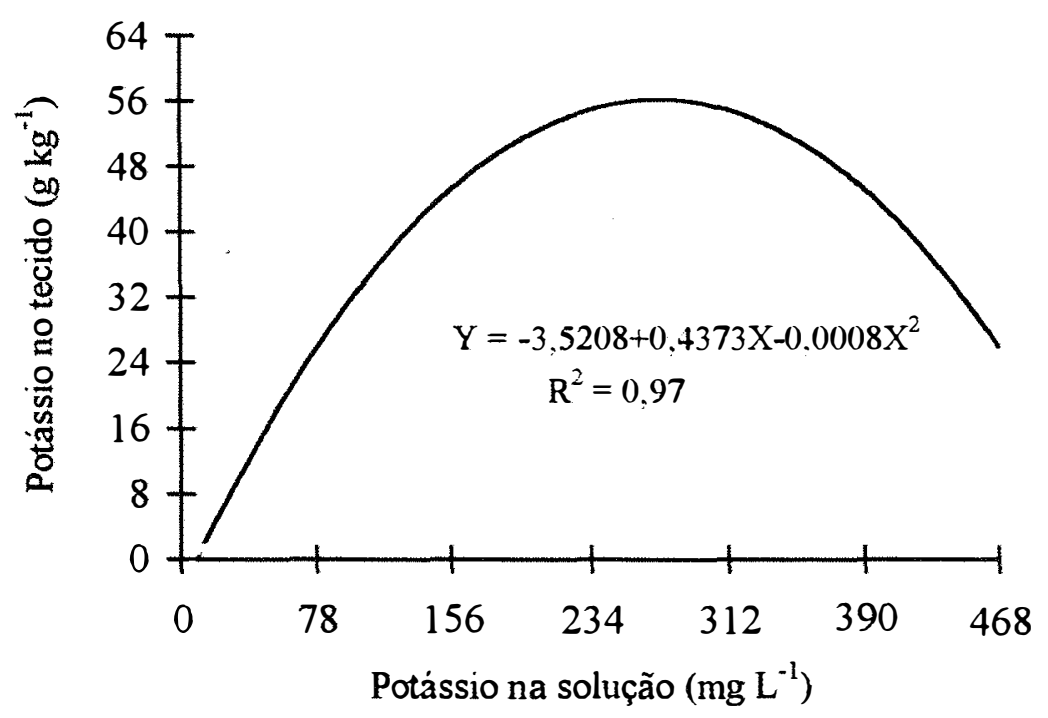

Figura 25 - Concentração de potássio nas lâminas de folhas velhas, no primeiro corte, da Brachiaria brizantha (Hochst ex A.Rich.) Stapf. cv. Marandu, em função das doses de potássio na solução nutritiva. 


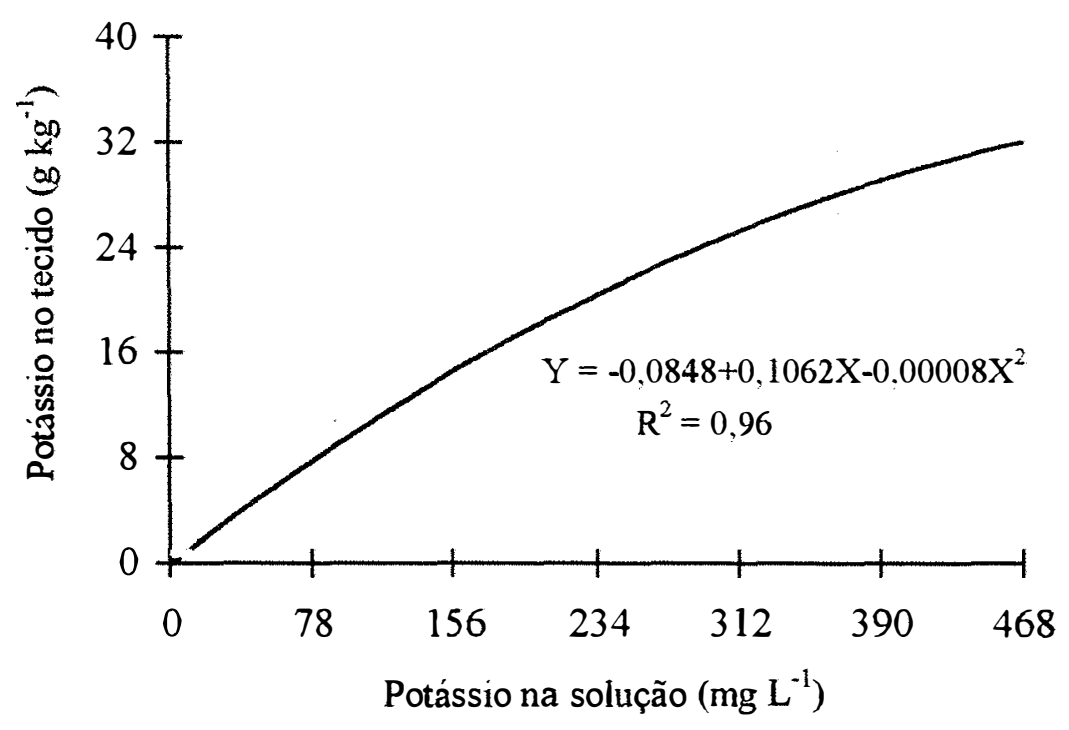

Figura 26 - Concentração de potássio nas lâminas de folhas velhas, no segundo corte, da Brachiaria brizantha (Hochst ex A.Rich.) Stapf. cv. Marandu, em função das doses de potássio na solução nutritiva.

\subsubsection{Colmos mais bainhas}

Os resultados mostraram que a concentração de potássio nos colmos

mais bainhas da Brachiaria brizantha (Hochst ex A.Rich.) Stapf. cv. Marandu teve incrementos significativos $(\mathrm{P}<0,01)$ com a adição de potássio na solução nutritiva, no material amostrado em ambos os cortes realizados.

No material coletado no primeiro corte a concentração de potássio variou segundo uma equação de segundo grau, em função das doses de potássio utilizadas na solução nutritiva. O ponto de máxima concentração de potássio 
nessa parte da gramínea ocorreria além do limite testado, com a dose de $478 \mathrm{mg} \mathrm{K}$ $\mathrm{L}^{-1}$ (Figura 27).

No segundo corte, a concentração de potássio nos colmos mais bainhas variou de acordo com uma equação de primeiro grau em função das doses de potássio utilizadas na solução nutritiva. Nos colmos mais bainhas da Brachiaria brizantha (Hochst ex A.Rich.) Stapf. cv. Marandu a concentração de potássio variou entre 5,54 e 32,72 $\mathrm{g} \mathrm{kg}^{-1}$, nesse corte (Figura 28). Para Mattos et al. (1996), trabalhando com o capim-Tanzânia-1, a concentração de potássio nessa parte da planta no primeiro corte variou conforme uma equação de primeiro grau e no segundo corte de acordo com um modelo quadrático de regressão.

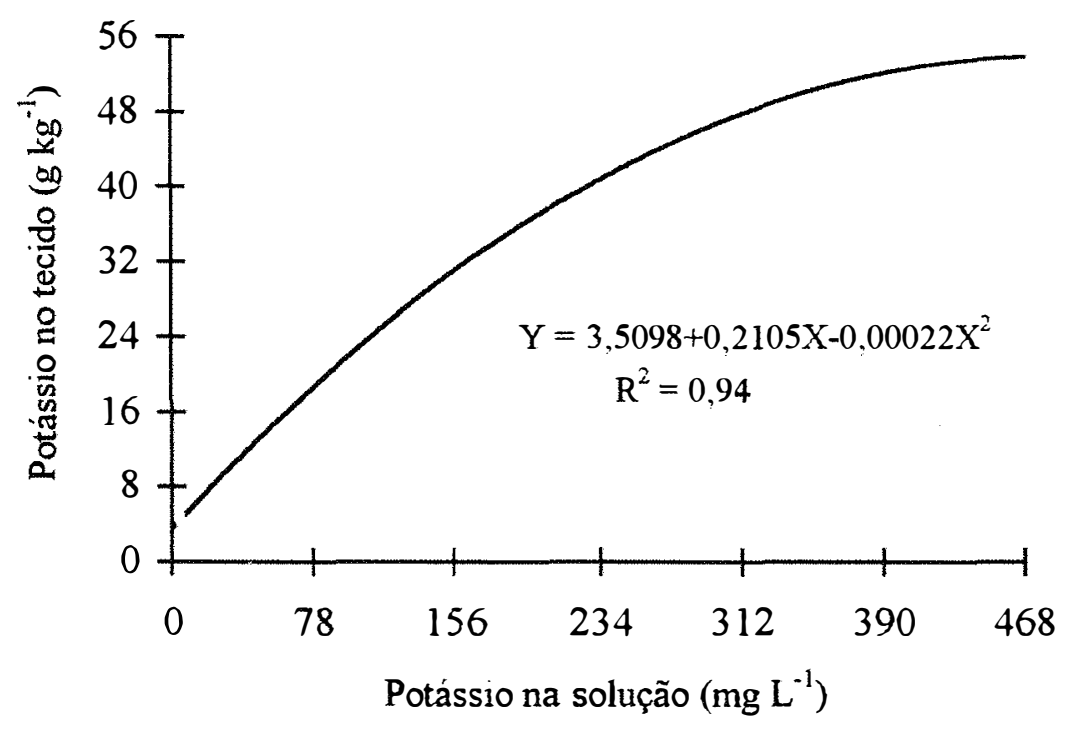

Figura 27 - Concentração de potássio nos colmos mais bainhas, no primeiro corte, da Brachiaria brizantha (Hochst ex A.Rich.) Stapf. cv. Marandu, em função das doses de potássio na solução nutritiva. 


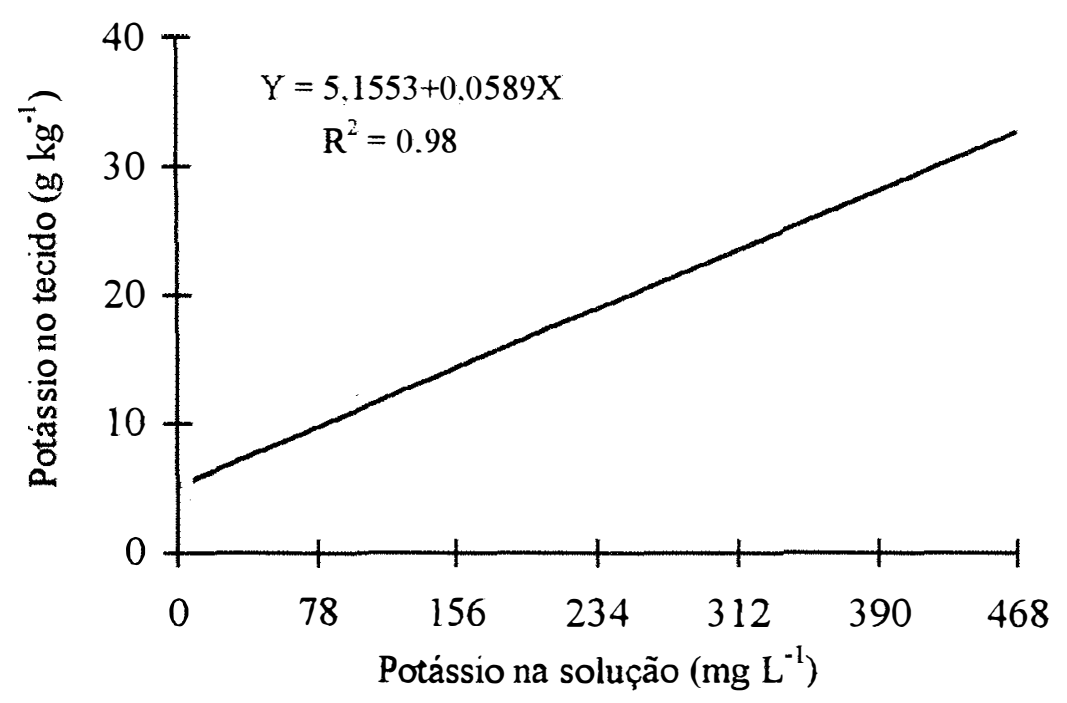

Figura 28 - Concentração de potássio nos colmos mais bainhas, no segundo corte, da Brachiaria brizantha (Hochst ex A.Rich.) Stapf. cv. Marandu, em função das doses de potássio na solução nutritiva.

\subsubsection{Raízes}

A concentração de potássio nas raízes da Brachiaria brizantha (Hochst

ex A.Rich.) Stapf. cv. Marandu também teve aumentos significativos $(P<0,01)$ com o fornecimento de potássio na solução nutritiva.

A concentração de potássio nessa parte da planta variou conforme uma equação de primeiro grau em função das doses de potássio utilizadas na solução nutritiva. A concentração de potássio nas raízes da gramínea continuaria se elevando além da maior dose utilizada de potássio na solução nutritiva, no presente experimento. Nas raízes da Brachiaria brizantha (Hochst ex A.Rich.) 
Stapf. cv. Marandu, a concentração de potássio nesse corte variou entre 1,08 e $21,02 \mathrm{~g} \mathrm{~kg}^{-1}$, em função das doses de potássio (Figura 29).

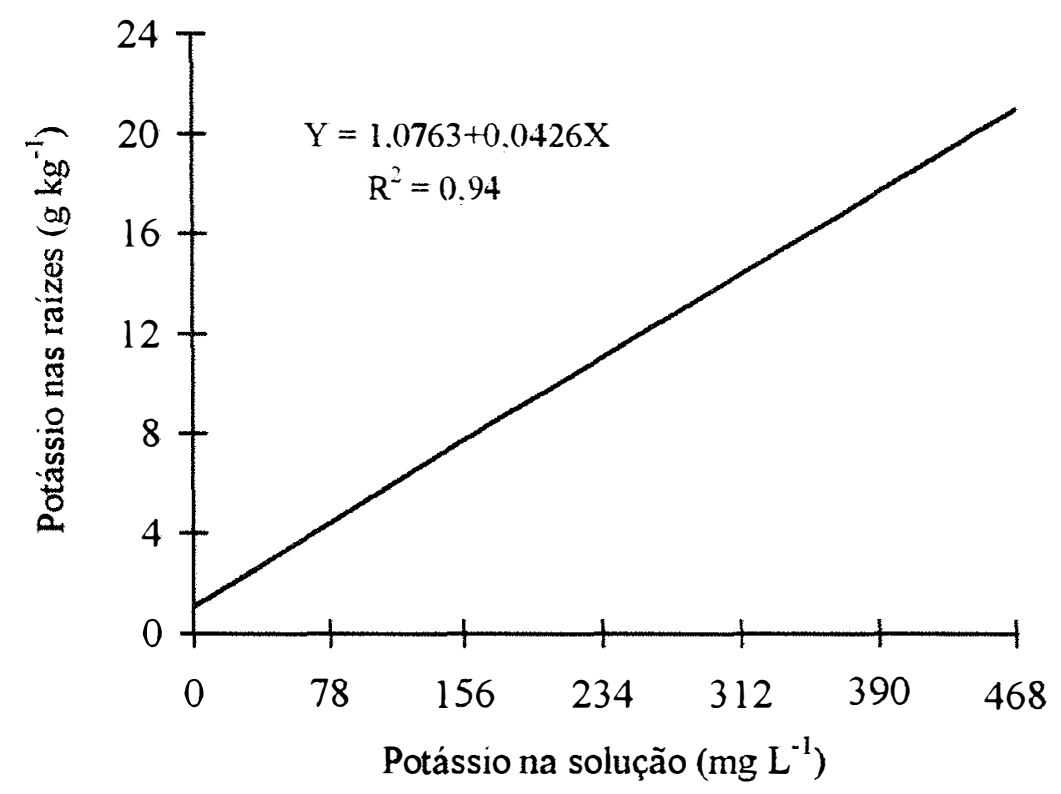

Figura 29 - Concentração de potássio nas raízes da Brachiaria brizantha (Hochst ex A.Rich.) Stapf. cv. Marandu, em função das doses de potássio na solução nutritiva.

\subsubsection{Sintomas visuais}

Aos dez dias após o transplante foram observados os primeiros sintomas de deficiência de potássio nas lâminas de folhas velhas da Brachiaria brizantha

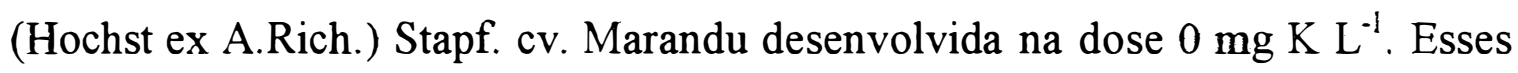


sintomas se manifestaram por uma clorose na borda das folhas, e avançaram em direção à nervura principal em forma de um "V" invertido.

Aos trinta e oito dias após o transplante da gramínea, por ocasião do primeiro corte, as plantas desenvolvidas nos vasos em que a dose de potássio era de $0 \mathrm{mg} \mathrm{K} \mathrm{L} \mathrm{K}^{-1}$ apresentaram uma intensa clorose nas folhas velhas primeiro período de crescimento. $\mathrm{O}$ mesmo ocorreu com menor intensidade nas folhas velhas das plantas submetidas à dose de $9,75 \mathrm{mg} \mathrm{K} \mathrm{L}^{-1}$.

No segundo corte, as plantas crescidas nas doses de $0 ; 9,75 ; 39$ e $78 \mathrm{mg}$ $\mathrm{K} \mathrm{L}^{-1}$ apresentavam sintomas visuais de deficiência de potássio nas lâminas de folhas velhas (Figura 30).

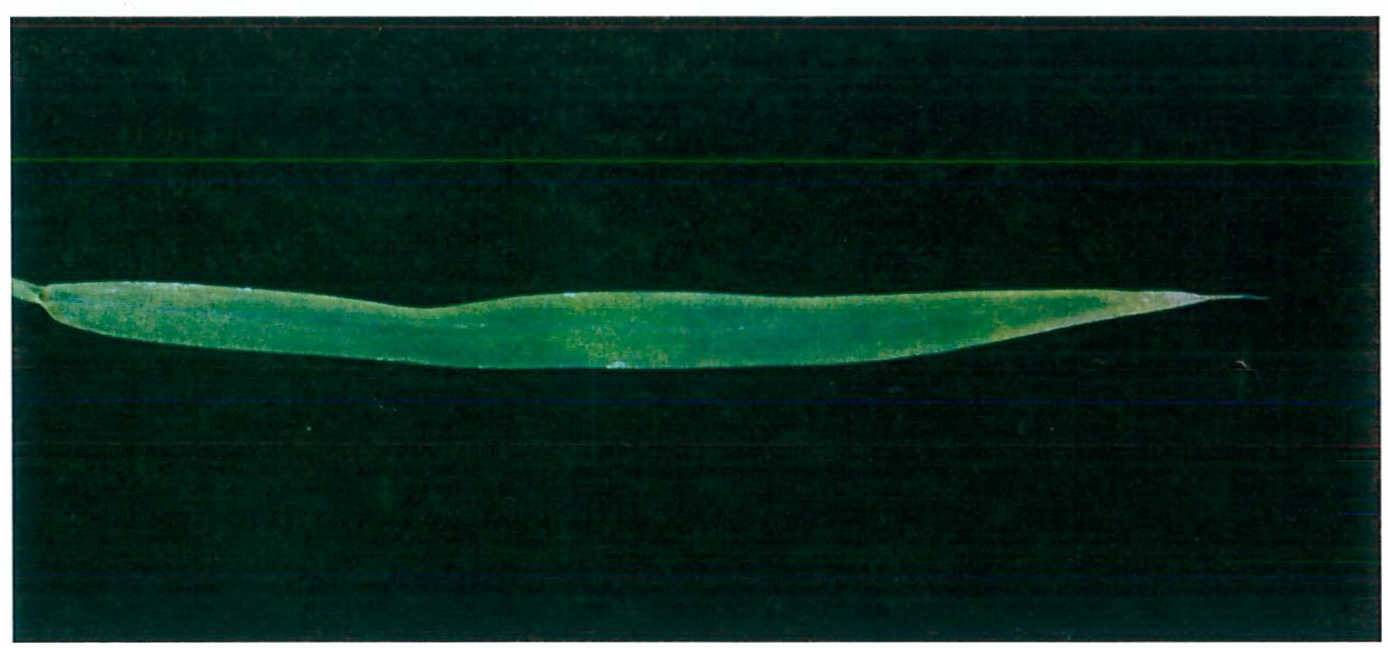

Figura 30 - Sintoma de deficiência de potássio em lâminas de folhas velhas da Brachiaria brizantha (Hochst ex A.Rich.) Stapf. cv. Marandu, verificado no tratamento $39 \mathrm{mg} \mathrm{K} \mathrm{L}^{-1}$ no segundo crescimento. 
Sintomas semelhantes a esses foram relatados por Carvalho et al. (1991) em Brachiaria decumbens Stapf., Monteiro et al.(1995) em Brachiaria brizantha cv. Marandu e Vicente-Chandler et al. (1962) e Monteiro et al. (1980) em Panicum maximum Jacq.

\subsubsection{Distribuição do potássio na parte aérea}

Na Brachiaria brizantha (Hochst ex A.Rich.) Stapf. cv. Marandu a quantidade de potássio presente nos componentes da parte aérea foi aumentada à medida em que se incrementou o potássio na solução nutritiva. A distribuição porcentual da quantidade de potássio nas folhas não-expandidas decresceu de $20 \%$ para $10 \%$ em ambos os cortes, em função da variação do potássio na solução. Nas lâminas de folhas velhas houve uma variação entre 26 e $35 \%$ tanto para o primeiro como para o segundo corte. Porém, nas lâminas de folhas novas a quantidade de potássio permaneceu em torno de 25 a $35 \%$ para ambos os cortes, enquanto para os colmos mais bainhas, no maior número de casos a quantidade representou $50 \%$ da quantidade total de potássio presente na parte aérea. Praticamente em todas as doses estudadas a maior parte do potássio esteve na fração colmos mais bainhas das plantas (Tabela 3). 
Tabela 3 - Distribuição porcentual da quantidade de potássio nas partes da parte aérea da Brachiaria brizantha (Hochst ex A.Rich.) Stapf. cv. Marandu submetida a doses de potássio, em cada um dos cortes.

\begin{tabular}{|c|c|c|c|c|c|c|c|c|}
\hline \multirow{2}{*}{$\mathrm{mg} \mathrm{K} \mathrm{L}^{-1}$} & \multicolumn{4}{|c|}{ Primeiro corte* } & \multicolumn{4}{|c|}{ Segundo corte* } \\
\cline { 2 - 9 } & FN & LN & LV & CB & FN & LN & LV & CB \\
\hline 0 & $* *$ & $* *$ & $* *$ & $* *$ & $* *$ & $* *$ & $* *$ & $* *$ \\
\hline 9,75 & 20,0 & 35,7 & 15,2 & 29,1 & 16,3 & 28,1 & 8,5 & 47,1 \\
\hline 39 & 27,3 & 26,6 & 10,0 & 36,1 & 26,4 & 25,2 & 4,7 & 43,7 \\
\hline 78 & 14,7 & 28,0 & 19,0 & 38,3 & 19,1 & 33,8 & 5,6 & 41,5 \\
\hline 156 & 13,0 & 29,5 & 19,2 & 38,3 & 15,1 & 25,4 & 8,4 & 51,1 \\
\hline 234 & 11,0 & 25,0 & 14,8 & 49,2 & 13,8 & 25,5 & 10,5 & 50,2 \\
\hline 312 & 10,1 & 28,1 & 19,2 & 42,6 & 11,7 & 26,8 & 12,6 & 48,9 \\
\hline 468 & 13,9 & 29,8 & 6,9 & 49,4 & 9,5 & 27,0 & 10,4 & 53,1 \\
\hline
\end{tabular}

${ }^{*} \mathrm{FN}=$ folhas não-expandidas; $\mathrm{LN}=$ lâminas de folhas novas; $\mathrm{LV}=$ lâminas de folhas velhas; $\mathrm{CB}=$ Colmos + Bainhas.

** Não foi determinado o teor de potássio, por insuficiência de material.

\subsubsection{Níveis críticos de potássio}

O estudo das correlações entre os teores de potássio nas quatro partes das plantas e a produção de matéria seca revelou que a correlação com mais elevado coeficiente entre essas variáveis foi obtido para as concentrações de potássio em folhas não-expandidas, em ambos os cortes. Os coeficientes de correlação foram iguais a $0,82^{* * *}$ e $0,93^{* * *}$, no primeiro e segundo cortes, respectivamente. 
O critério estabelecido por Ulrich e Hill (1973), que define o nível crítico como a concentração do nutriente que corresponde a $90 \%$ da produção máxima da cultura, foi aplicado.

A relação entre as concentrações de potássio e a produção de matéria seca da parte aérea foi traduzida, em ambos os cortes, por modelo quadrático para folhas não-expandidas. Para primeiro corte e para o segundo corte, o nível crítico de potássio nas folhas não-expandidas (para 90\% da máxima produção) seria de 29 e de $30 \mathrm{~g} \mathrm{~kg}^{-1}$ (Figuras 31 e 32).

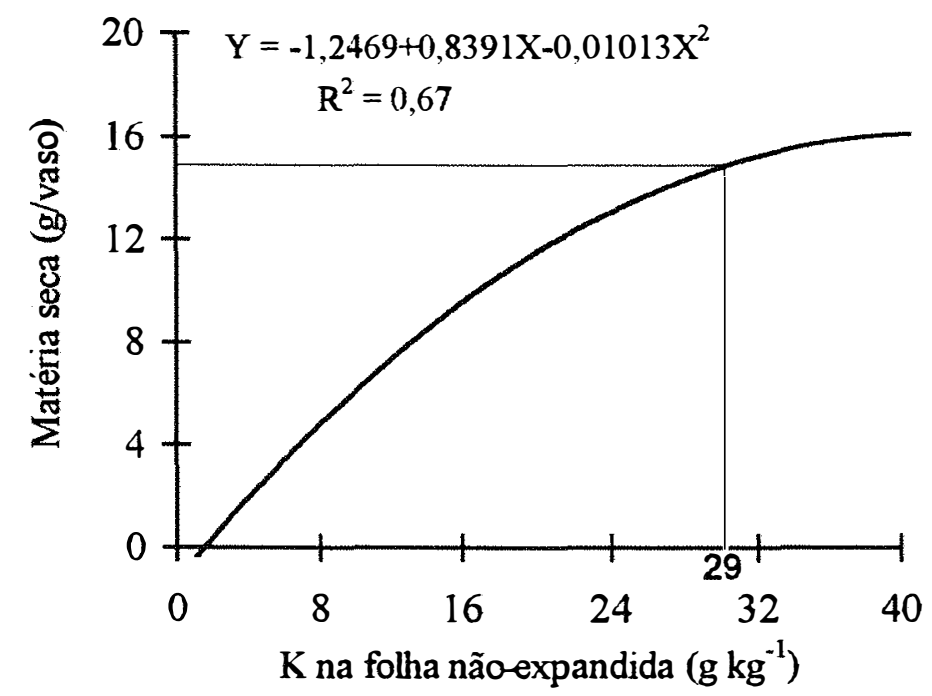

Figura 31 - Relação entre a produção de matéria seca da parte aérea e a concentração de potássio nas folhas não-expandidas de Brachiaria brizantha (Hochst ex A.Rich.) Stapf. cv. Marandu, no primeiro corte. 


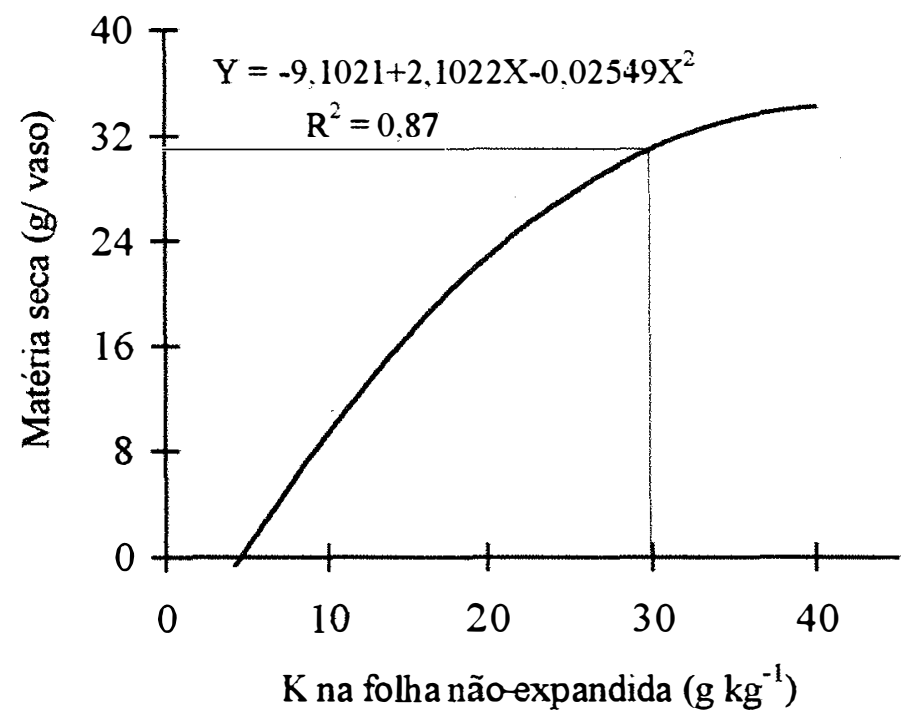

Figura 32 - Relação entre a produção de matéria seca da parte aérea e a concentração de potássio nas folhas não-expandidas de Brachiaria brizantha (Hochst ex A.Rich.) Stapf. cv. Marandu, no segundo corte.

Para os resultados do primeiro corte das plantas, a relação entre a concentração de potássio nas lâminas de folhas novas e a produção de matéria seca esperada não foi significativa $(\mathrm{P}>0,05)$. Em tais situações tratou-se de buscar o valor da concentração de potássio nas lâminas de folha nova através da concentração de potássio nas folhas não expandidas e a concentração de potássio nas lâminas de folhas novas. Pelo uso da equação $Y=-11,15+1,36 \mathrm{X}(\mathrm{r}=0,94)$ entre essas duas variáveis foi possível obter o valor de nível crítico de $29 \mathrm{~g} \mathrm{~kg}^{-1}$, nas lâminas de folha nova.

No segundo corte a correlação entre os teores de potássio nas partes das plantas (exceto as folhas não-expandidas) e a produção de matéria seca revelou que o mais elevado coeficiente entre essas variáveis foi obtido para as 
concentrações de potássio nas lâminas de folhas novas $\left(0,91^{* * *}\right)$. A relação entre as concentrações de potássio e a produção de matéria seca foi traduzida, no segundo corte, por modelo quadrático para lâminas de folhas novas, através do qual se obteve o nível crítico de $22 \mathrm{~g} \mathrm{~kg}^{-1}$ (Figura 33).

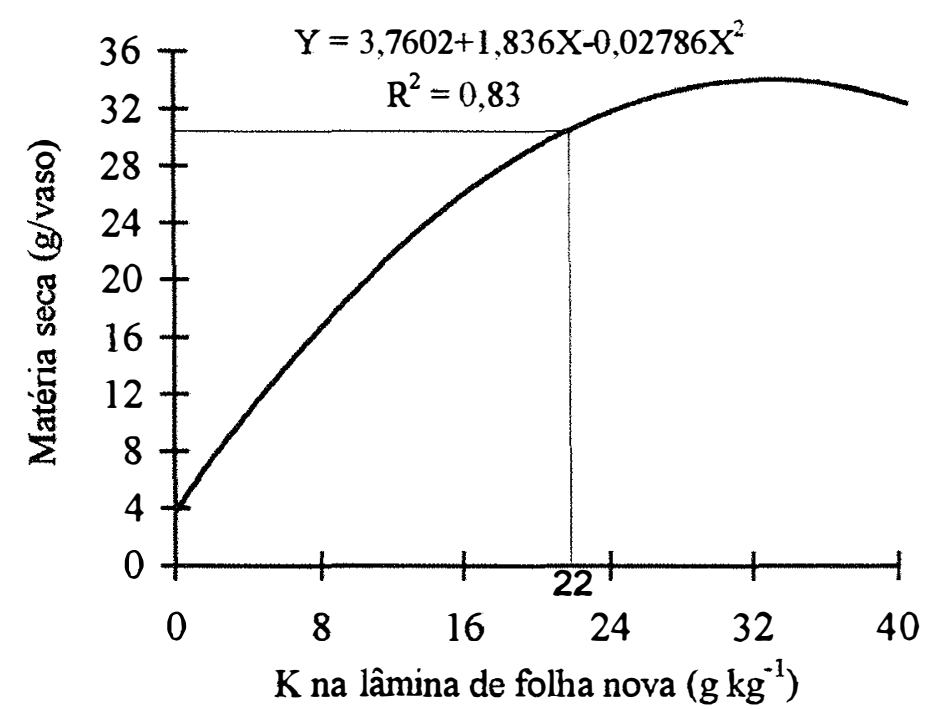

Figura 33 - Relação entre a produção de matéria seca da parte aérea e a concentração de potássio nas lâminas de folhas novas de Brachiaria brizantha (Hochst ex A.Rich.) Stapf. cv. Marandu, no segundo corte.

Carvalho et al. (1989), não separando folhas não-expandidas, lâminas de folhas novas e lâminas de folhas velhas, determinaram valores de níveis críticos de potássio na matéria seca da parte aérea da braquiária na faixa de 10,0 a $15,0 \mathrm{~g}$ $\mathrm{kg}^{-1}$. Esta diferença pode ser atribuída ao fato do potássio translocar de partes mais velhas para mais novas da planta, o que certamente resulta em mais elevada concentração na parte mais nova que na parte aérea toda. 
Pela praticidade na amostragem e de acordo com a consideração apresentada, a utilização das lâminas de folhas novas pode ser aconselhada para fins de diagnose nutricional de potássio em Brachiaria brizantha (Hochst ex A.Rich.) cv. Marandu. O nível crítico de potássio neste componente da planta, para esta espécie, está entre 22 e $29 \mathrm{~g} \mathrm{~kg}^{-1}$. 


\section{CONCLUSÕES}

Nas condições em que foi desenvolvido o presente trabalho, as seguintes conclusões são apresentadas:

- O incremento de potássio na solução nutritiva proporcionou aumentos na produção de matéria seca da parte aérea, na produção de matéria seca das raízes e no perfilhamento, em ambas as espécies;

- A concentração de potássio nos componentes da parte aérea e nas raízes aumentou em função das doses de potássio presentes na solução nutritiva, em ambas as espécies;

- Na diagnose nutricional de potássio nessas forrageiras recomenda-se a amostragem das lâminas de folhas novas, nas quais o nível crítico é de 20 a $23 \mathrm{~g}$ $\mathrm{kg}^{-1}$ na Brachiaria decumbens Stapf. cv. Basilisk e de 22 a $29 \mathrm{~g} \mathrm{~kg}^{-1}$ na Brachiaria brizantha (Hochst ex A.Rich.) Stapf. cv. Marandu. 


\section{REFERÊNCIAS BIBLIOGRÁFICAS}

ABREU, J.B.R. Níveis de nitrogênio e proporções de nitrato e amônio afetando produção, atividade da redutase do nitrato e composição de três gramíneas forrageiras. Piracicaba, 1994. 103p. Dissertação (Mestrado) - Escola Superior de Agricultura "Luiz de Queiroz", Universidade de São Paulo.

ALCÂNTARA, P.B. Origem das braquiárias e suas características morfológicas de interesse forrageiro. In: ENCONTRO PARA DISCUSSÃO SOBRE CAPINS DO GÊNERO Brachiaria, 1., Nova Odessa, 1986. Anais. Nova Odessa, Instituto de Zootecnia, 1987. p. 1-18.

BATAGLIA, O.C.; DECHEN, A.R.; SANTOS, W.R. Princípios da diagnose foliar. In: ALVAREZ, V.H.; FONTES, L.E.F.; FONTES, M.P.F. (Ed). O solo nos grandes domínios morfoclimáticos do Brasil e o desenvolvimento Sustentado. Viçosa: SBCS, 1996. cap. 42, p. 647-660.

BOGDAN, A.V. Tropical pasture and fodder plants. Longman, New York, 1977. $455 \mathrm{p}$.

BUFARAH, G.; PEDREIRA, J.V.S.; MATTOS, H.B. Adaptação de plantas forrageiras no litoral sul do Estado de São Paulo. Boletim de Indústria Animal, v. 39, n.2, p. 81-92, 1982. 
CARRIEL, J.M.; WERNER, J.C.; ABRAMIDES, P.L.G.; MONTEIRO, F.A.; MEIRELLES, N.M.F. Limitações nutricionais de um solo Podzólico Vermelho-Amarelo para o cultivo de três gramíneas forraageiras. Boletim de Indústria Animal, v. 46, n. 1, p. 61-73, 1989.

CARVALHO, M.M.; MARTINS, C.E.; VERNEQUE, R. da S.; SIQUEIRA, C. Resposta de uma espécie de braquiária à fertilização com nitrogênio e potássio em um solo ácido. Revista Brasileira de Ciência do Solo, v. 15, n.2, p.195 -200 , 1991.

CENSO AGROPECUÁRIO. Censos Econômicos de 1985. Brasil. Rio de janeiro: IBGE, n.1, 1992. 399p.

CLAYTON, W.D.; RENVOIZE,S.A. Gramineae (Part 3). In: Flora of tropical East Africa. POLHIL, R.M. (Ed.). Royal Botanical Gardens, Kew, England, 1982. 898p.

CORRÊA, B.D. Doses de nitrogênio e de magnésio afetando aspectos produtivos e bioquímicos dos capins Colonião, Tanzânia-1 e Vencedor. Piracicaba, 1996. 76p. Dissertação (Mestrado) - Escola Superior de Agricultura "Luiz de Queiroz", Universidade de São Paulo. 
CORREAA, B.D.; SANTOS, A.R.; SILVA, A.A.; MATTOS, W.T.; MONTEIRO, F.A. Rendimento de matéria seca, concentração de nitrogênio e perfilhamento do Capim-Vencedor (Panicum maximum) sob doses de nitrogênio. (compact disc) In: CONGRESSO LATINO-AMERICANO DE CIÊNCIA DO SOLO, 13., Águas de Lindóia, 1996. Solo-suelo 96: trabalhos. Piracicaba: SBCS/SLCS, 1996.

CRIPPS, R.W.; YOUNG, J.L.; LEONARD, A.T. Effects of potassium and lime applied for Coastal bermudagrass production on sandy soil. Soil Science Society of America Journal, v. 53, n. 1, p. 127-132, 1989.

EICHHORN JUNIOR, M.M.; HALLMARK, W.B. Nutrient levels in plant tissue indicate optimum potash rates for Coastal bermudagrass. Better Crops with Plant Food. v. 73, n.2, p. 16-17, 1989.

EPSTEIN, E. Nutrição mineral das plantas: princípios e perspectivas. São Paulo: Editora da Universidade de São Paulo, 1975. 341p.

EVENHUIS, B.; WAARD, P.W.F. Principles and practices in plant analysis. In: FAO Soils. Rome, 1980. p. 152-163.

FAQUIN, V.; HOFFMANN, C.R.; EVANGELISTA, A.R.; GUEDES, G.A.A. O potássio e o enxofre no crescimento da braquiária e do colonião em amostras de um Latossolo da região Noroeste do Paraná. Revista Brasileira de Ciência do Solo, v. 19, n.3, p. 87-94, 1995. 
FERRARI NETO, J. Limitações nutricionais para o colonião (Panicum maximum Jacq.) e braquiária (Brachiaria decumbens Stapf.) em Latossolo da região Noroeste do Estado do Paraná. Lavras, 1991. 126p. Dissertação (Mestrado) Escola Superior de Agricultura de Lavras.

FRANÇA, A.F.S.; HAAG, H.P. Nutrição mineral de gramíneas tropicais. I. Carências nutricionais de Capim Tobiatã (Panıcum maximum Jacq.). Anais da Escola Superior de Agicultura "Luiz de Queiroz", v. 62, p. 83-95, 1985.

GALLO, J.R.; HIROCE, R.; BATAGLIA, O.C.; FURLANI, P.R.; FURLANI, A.M.C.; MATTOS, H.B.; SARTINI, H.J.; FONSECA, M.P. Composição química inorgânica de forrageiras do Estado de São Paulo. Boletim de Industria Animal, v. 31, n.1, p. 115-137, 1974.

GHISI, O.M.A.A.; PEDREIRA, J.V.S. Características agronômicas das principais Brachiaria. In: ENCONTRO PARA DISCUSSÃO SOBRE CAPINS DO GÊNERO Brachiaria, Nova Odessa, 1986. Anais. Nova Odessa, Instituto de Zootecnia, 1987. p. 19-40.

GOMIDE, J.A.; NOLLER, C.H.; MOTT,G.O.;CONRAD, J.H.; HILL, D.L. Mineral composition of six tropical grasses as influenced by plant age and nitrogen fertilization. Agronomy Journal, v. 61, n.1, p. 120-123, 1969.

GONZALES, Y.; OILDA, T.S. Niveles críticos de K em Guinea comúm SIH-127, Buffel cv. Biloela y Bermuda cv. Coastcross-1. Pastos y Forrages, v. 5, n.1, p. $49-57,1982$. 
GONZALES, S.B.; RAMOS, N.; SANCHEZ, M. The effect of nitrogen fertilization on the mineral compostion of five Cynodon species. Cuban Journal of Agricultural Science, v. 17, n.2, p. 213-221, 1983.

HERNÁNDEZ, M.; CÁRDENAS, M. Respuesta del pasto estrella jamaicana a niveles de NPK en un suelo ferralitico cuarcitico. Pasto y Forrages, v. 13, n.3, p.273-277, 1990.

IBPGR, International Board for Plant Genetic Resources. Tropical and Sub tropical forages. Report of Working group. Rome, FAO. 1984. 29p.

JONES JR., J.B.; STEYN, W.J.A. Sampling, handling, and analyzing plant tissue sample. In: WALSH, L.M.; BEATON, J.D. (Ed.) Soil testing and plant analysis. Madison: Soil Science Society of America, 1973 p. 249-270.

KAPPEL, L.C.; MORGAN, E.B.; KILGORE, L.; INGRAHAM, R.H.; BABCOCK, D.K. Seasonal change of mineral content of southern forages. Journal of Dairy Science, v. 68, n. 7, p. 1823-1827, 1985.

MARTIM, R.A. Doses de nitrogênio e de potássio para produção e composição dos Capins Coastcross-1 e Tifton 85 em um Latossolo Vermelho-Amarelo. Piracicaba, 1997. 109p. Dissertação (Mestrado) - Escola Superior de Agricultura “Luiz de Queiroz", Universidade de São Paulo.

MARTIM, W.E.; MATOCHA, J.E. Plant analysis as an aid in the fertilization of forage crops. In: WALSH, L.M.; BEATON, J.D., (Ed.) Soil testing and plant analysis. Madison: Soil Science Society of America, 1973. p. 393-426. 
MATTOS, W.T.; SILVA, A.A.; SANTOS, A.R.; CORREAA, B.D.; MONTEIRO, F.A. Produção de matéria seca e concentração de potássio em Capim -Tanzânia-1 (Panicum maximum) submetido a doses de potássio em solução nutritiva (compact disc). In: CONGRESSO LATINO-AMERICANO DE CIÊNCIA DO SOLO, 13.,Águas de Lindóia, 1996. Solo-suelo 96: trabalhos. Piracicaba: SBCS/SLCS, 1996.

MESA, A.R.; MENDOZA, F.; AVILA, V. Rendimiento, composicion química y niveles críticos de potássio em cuatro gramíneas tropicales.Pastos y Forrages. v. 12, n. 1, p. $43-51,1989$.

MONTEIRO, F.A.; MARTIM, R.A.; MATTOS, W.T. Brachiaria brizantha response to phosphorus rates in the nutrient solution. In: International Grassland Congress, 18., Winnipeg, 1997. /No prelo/

MONTEIRO, F. A.; LIMA, S. A. A.; WERNER, J. C.; MATTOS, H. B. Adubação potássica em leguminosas e em capim-colonião (Panicum maximum Jacq.) adubado com níveis de nitrogênio ou consorciado com leguminosas. Boletim de Indústria Animal, v. 37, n. 1, p. 127-47, 1980.

MONTEIRO, F. A.; RAMOS, A. K. B.; CARVALHO, D. D. de; ABREU, J. B. R. de; DAIUB, J. A. S.; SILVA, J. E. P.; NATALE, W..Cultivo de Brachiaria brizantha Stapf. cv. Marandu em solução nutritiva com omissões de macronutrientes. Scientia Agricola, v. 52, n. 1, p.135-41, 1995. 
MUNSON, R.D.; NELSON, W.L. Principles and pratices in plant analysis. In: WALSH, L.M.; BEATON, J.D. (Ed.) Soil testing and plant analysis. Madison: Soil Science Society of America, 1973. p. 223-248.

NUNES, S.G.; BOOCK, A.; PENTEADO, M.I. de O.; GOMES, D.T. Brachiaria brizantha cv. Marandu.. Campo Grande, EMBRAPA-CNPGC, 1985. 31 p. (EMBRAPA-CNPGC. Documentos, 21).

OKHI, K. Critical nutrient levels related to plant growth and some physiology processes. Journal of Plant Nutrition, v. 10, n.(9-16), p. 1583-1590, 1987.

PALHANO, A.L. Recrutamento de nutrientes e valor nutritivo do Cynodon dactylon (L.) Pers. cv. Coastcross-1. Piracicaba, 1997. 109p. Dissertação (Mestrado) - Escola Superior de Agricultura "Luiz de Queiroz", Universidade de São Paulo.

PRITCHARD, A.J. Apomixis in Brachiaria decumbens, Stapf. Journal Australian Institute Agriculture Science, v. 31, n.2, p. 265, 1967.

RAIJ, B. van. Fertilidade do solo e adubação. São Paulo. (Ed.) Agronômica Ceres. Associação Brasileira para Pesquisa da Potassa e do Fosfato, 1991. $343 p$.

RAIJ, B. van; QUAGGIO, J.A. Disponibilidade de potássio em solos para Capimbraquiária cultivado em solos. Bragantia, v. 43, n.2, p. 531-539, 1984. 
RAO, I.M.; KERRIDGE, P.C.; MACEDO, M.C.M. Nutritional requirements of Brachiaria and adaptation to acid soil. In: MILES, J.W.; MAASS, B.L.; VALLE, C.B. do (Ed.) Brachiaria: Biology, Agronomy, and Improvement. Cali: CIAT/EMBRAPA, 1996. p. 53-71.

SALINAS, J. G.; GUALDRON, R. Adaptación y requerimientos de fertilizatión de Brachiaria humidicola (Rendle) Schweikt en la altilanura plana de los Lhanos Orientales de Colombia. In: SIMPÓSIO SOBRE O CERRADO: SAVANAS, ALIMENTOS E ENERGIA, 6., Brasília, 1982. Planaltina, EMBRAPA-CPAC, 1988. p. 457-471.

SARRUGE, J. R. Soluções nutritivas. Summa Phytopathologica. Jaguariúna, v. 1,n.3, p.231-3, 1975.

SARRUGE, J. R.; HAAG, H. P. Análises químicas em plantas. Piracicaba, Escola Superior de Agricultura "Luiz de Queiroz", 1974. 56p.

SAS INSTITUTE INCORPORATION. Property Software Release 6.08. Cary, NC USA, 1989.

SILVA, A. A.; MATTOS, W. T.; MONTEIRO, F. A. Respostas de capimTanzânia-1 (Panicum maximum) a níveis de potássio em solução nutritiva. In: CONGRESSO BRASILEIRO DE CIÊNCIA DO SOLO, 25, Viçosa, 1995, Resumos... Viçosa: Sociedade Brasileira de Ciência do Solo, 1995. p. 1046-7.

SMITH, P.F. Mineral analysis of plant tissues. Annual Review of Plant Phisiology, v. 13, n.1, p. 81-108, 1962. 
SOARES FILHO, C.V. Recomendações de espécies e variedades de Brachiaria para diferentes condições. In: SIMPÓSIO SOBRE MANEJO DA PASTAGEM, Piracicaba, 1994. Anais. Piracicaba: FEALQ, 1994. p. 25-48

TOLEDO, J.M. Pastures en trópico húmedo: perspectiva global. In: SIMPÓSIO DO TRÓPICO ÚMIDO, 1., Belém, 1984. Resumos... Belém: EMBRAPA/CPATU, 1984. p.315-316.

ULRICH, A.; HILLS, F.J. Principles and pratices of plant analysis. In: HARDY, G.W., (Ed.) Soil testing and plant analysis. Madison: Soil Science Society of America, 1967.pt. 2, p. 11-24.(Special Publication Series)

ULRICH, A.; HILLS, F.J. Plant analysis as an aid in fertilizing sugar crops: part I. Sugar beets. Principles and pratices of plant analysis. In: WALSH, L.M.; BEATON, J.D., (Ed.) Soil testing and plant analysis. Madison: Soil Science Society of America, 1973. p. 271-288.

VICENTE-CHANDLER, J.; PEARSON, R. W.; ABRUÑA, F.; SILVA, S. Potassium fertilization of intensively managed grasses under humid tropical conditions. Agronomy Journal. Madison, v. 54, n. 5, p. 450-3, 1962.

WERNER, J.C.; HAAG, H.P. Estudos sobre a nutrição mineral de alguns capins tropicais. Boletim de Indústria Animal, v. 29, n.1, p.191-245, 1972. 